\title{
Article \\ Potential for Coastal and Offshore Aquaculture in Portugal: Insights from Physico-Chemical and Oceanographic Conditions
}

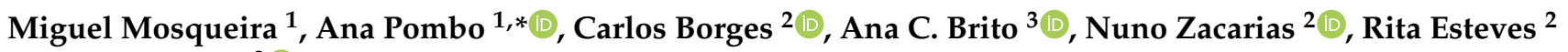 \\ and Carla Palma ${ }^{2}$ (i)
}

check for updates

Citation: Mosqueira, M.; Pombo, A.; Borges, C.; Brito, A.C.; Zacarias, N.; Esteves, R.; Palma, C. Potential for Coastal and Offshore Aquaculture in Portugal: Insights from Physico-

Chemical and Oceanographic

Conditions. Appl. Sci. 2022, 12, 2742. https://doi.org/10.3390/ app12052742

Academic Editor: Mauro Marini

Received: 29 December 2021 Accepted: 25 February 2022 Published: 7 March 2022

Publisher's Note: MDPI stays neutral with regard to jurisdictional claims in published maps and institutional affiliations.

Copyright: (c) 2022 by the authors. Licensee MDPI, Basel, Switzerland. This article is an open access article distributed under the terms and conditions of the Creative Commons Attribution (CC BY) license (https:/ / creativecommons.org/licenses/by/ $4.0 /)$.
1 MARE-Marine and Environmental Sciences Centre, ESTM, Polytechnic Institute of Leiria, Edifício CETEMARES, Avenida Porto de Pesca, 2520-641 Peniche, Portugal; miguel.m.mosqueira@ipleiria.pt

2 Instituto Hidrográfico, Rua das Trinas 49, 1249-093 Lisboa, Portugal; carlos.borges@hidrografico.pt (C.B.); nuno.zacarias@hidrografico.pt (N.Z.); rita.esteves@hidrografico.pt (R.E.); carla.palma@hidrografico.pt (C.P.)

3 MARE-Marine and Environmental Sciences Centre, Faculdade de Ciências, Universidade de Lisboa, Campo Grande, 1749-016 Lisboa, Portugal; acbrito@fc.ul.pt

* Correspondence: ana.pombo@ipleiria.pt

\begin{abstract}
Physico-chemical and biological parameters along the Portuguese coast were analyzed to evaluate the potential to produce aquatic species of economic interest. Water samples were collected in 2018 and 2019 in five different areas of the Portuguese coast. Currents data were collected between 2018 and 2020 and historical waves height data from 1988 to 2019. According to the results, there is a wide variety of species that can be considered for production. The northernmost area presented the lowest temperature, as well as the highest levels of chlorophyll $a$, and nitrate. Under such conditions, the rearing of salmon Salmo salar, mussel Mytilus edulis, scallop Pecten maximus, macroalgae Porphyra umbilicalis, and Undaria pinnatifida can be considered. Regarding the southernmost area, due to the highest temperature, this area seems appropriate for the production of meager Argyrosomus regius, sea bream Sparus aurata, sea bass Dicentrarchus labrax, and greater amberjack Seriola dumerili. This study highlights the challenges in deploying aquaculture structures on the Atlantic coast due to its oceanographic conditions. Site selection for aquaculture is a complex process and pilot studies are essential to analyze the feasibility of developing offshore aquaculture along the coast of Portugal.
\end{abstract}

Keywords: spatial planning; Portuguese coast; site selection; species selection

\section{Introduction}

\subsection{Aquaculture}

The current state of aquaculture plays a critical role in providing food and employment to millions of people, many of whom live and depend on aquaculture for subsistence. For this reason, aquaculture has been identified as the food industry with the highest annual growth rate with 5.3 percent per year in the period 2001-2018 [1]. Aquaculture in Portugal reached 14,336 mts in 2019 corresponding to an increase of $2.5 \%$ compared to the previous year [2]. Most of the Portuguese aquaculture is developed in old salt pans in the central and southern areas of Portugal, while freshwater aquaculture is scattered throughout the northern and central regions. In any case, land-based production in aquaculture recirculating systems (RAS) or in natural systems can be an option to increase the aquaculture production and can be appropriate for some species such as flat fishes, e.g., turbot (Scophthalmus maximus), Senegalese sole (Solea senegalensis), or to produce new species such as the sea urchin Paracentrotus lividus [3,4] and the sea cucumber Holothuria mammata [5]. However, the limited areas for aquaculture production mean that offshore aquaculture may be seen as a solution for other species rearing. Offshore aquaculture has been accepted as a sustainable, economical, and viable form of food production in many coastal nations [6-8]. This is mainly due to the problems related to coastal pollution, the use of resources [9], and the lack of suitable sites for production. To ensure the correct choice for new aquaculture 
facilities offshore, it is necessary to understand all factors that influence the well-being of the organisms [10]. It is required to ensure adequate physico-chemical conditions, such as nitrogenous compounds (ammonia, nitrite, and nitrate), phosphate, silicate, dissolved oxygen, $\mathrm{pH}$, temperature, and chlorophyll $a$. There is a very close relationship between the water quality and the survival and health of organisms, where poor water quality can cause mortality, slow growth, and can induce stress, reducing the farmed animals' health and welfare leading to increased susceptibility to diseases. The effort required by fishes, bivalves, or other aquatic organisms exposed to suboptimal water quality creates impacts and diverts energy from growth. Furthermore, survival declines as the water quality parameters diverge from the optimum for a species. According to Boyd [11], most of the problems with water quality in aquaculture result from the less-than-optimal quality of the water. Some of the major water-quality stressors are inappropriate values of water temperature, salinity, $\mathrm{pH}$, or suboptimal concentrations of dissolved oxygen, ammonia nitrogen, and nitrite among others. From the standpoint of aquaculture implementation, location is the most relevant step as it is the broadest criterium. Knowledge of hydrographic conditions, such as swells and currents, is fundamental to deploying offshore aquaculture cages and other structures. Adverse marine conditions can cause damage to the equipment and lead to stock losses.

\subsection{Fish Aquaculture}

In Portugal, the production in aquaculture of marine fish represented $27.6 \%$ in 2018 and $46.8 \%$ in 2019 , where $90 \%$ and $96 \%$ respectively were devoted to turbot, sea bream, and seabass [2,12]. In fact, according to the national statistics, there was a significant increase in the production of turbot $(+38.7 \%)$ with $3580 \mathrm{mts}$, sea bream (+117.5\%) with $1953 \mathrm{mts}$, and sea bass $(+341.7 \%)$ which reached $882 \mathrm{mts}$ in 2019 . The increased production in aquaculture facilities of turbot and sea bass was due to more efficient production methods. Although this increase is a positive sign, national production still has a great potential for growth. The expansion of the fish industry may be dependent on the implementation of offshore submersible cages [13]. In this context, oceanographic conditions and temperature are key factors for the selection of species to implement aquaculture facilities in new locations. Temperature strongly influences the metabolism, feeding rate, and growth $[14,15]$ and is also one of the most relevant parameters in fish farms for growing juveniles [16,17].

\subsection{Bivalve Aquaculture}

Bivalve mollusks rearing reached $15 \%$ of the total world catch in 2018, equivalent to 17.7 million mts [1]. In Portugal, bivalve production has the potential to increase due to geographical conditions [18]. The majority of bivalve production is focused on clam and oysters. Unlike what happened with fish, in 2019 the production of bivalves decreased compared to 2018. Clams remained the most affected species ( $3276 \mathrm{mts}$ ) having decreased $17.5 \%$, followed by oysters, which, with $1690 \mathrm{mts}$, had a reduction of about half $(-51.0 \%)$ compared to 2018. Mussels, with a production of $1457 \mathrm{mts}$, also decreased by $16.5 \%$. This decrease in oysters and mussels is due to the fact that some offshore farmers have ceased to operate [2]. It is essential to evaluate the limiting factors for growth such as phytoplankton concentration, which is one of the most influential factors in the development of bivalves. Its availability allows the elimination of feed costs and simplifies farming techniques to produce a high-quality protein and essential fatty acids [19,20], and even a benefit to the environment [21-23].

\subsection{Macroalgae Aquaculture}

Portugal's maritime area has one of the largest and most diverse macroalgae communities in Europe [24], but its rearing is very scarce and currently concentrated in a single company. In recent decades, the interest in macroalgae has increased in Europe due to their biotechnological potential, bioactivities, and nutritional value for human consumption $[25,26]$. Nutrient availability, such as nitrogen compounds and phosphates is essential 
for its production. Temperature and solar irradiance also must be taken into consideration as these parameters influence the growth and chemical composition of macroalgae [27].

\subsection{Objectives}

This study is part of the "Aquimar project-General characterization of aquaculture areas for the establishment of marine cultures" which aims to characterize the oceanographic, physico-chemical, geochemical, and biological conditions of the Portuguese coastal waters in order to optimize the selection of sites and species for coastal and offshore aquaculture. Considering that there is an extensive Portuguese coastline that could be used for the development of marine aquaculture, the results of physical, chemical, and biological parameters such as temperature, ocean currents, waves, ammonia, nitrite, nitrate, silicate, phosphate, dissolved oxygen, salinity, $\mathrm{pH}$, and chlorophyll $a$ were compared with the ideal growth factors for some fish, bivalves and macroalgae species with economic interest and potential for aquaculture.

\section{Materials and Methods}

\subsection{Field Surveys}

This study was conducted alongside the Portuguese Coast in 5 areas (Figure 1) with field surveys in 2 different periods between 5 and 26 October 2018 (2018) and between 13 April and 14 May 2019 (2019).

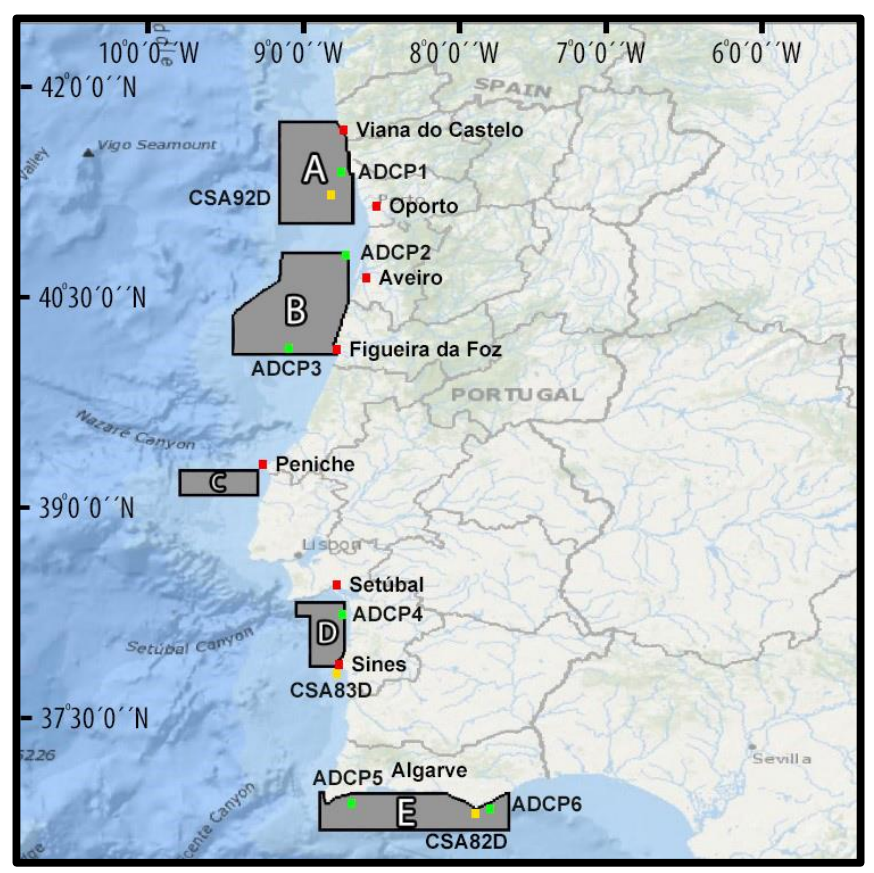

Figure 1. Map of the 5 study areas from the Aquimar project (A-Area A (between Viana do Castelo and Oporto); B-Area B (between Aveiro and Figueira da Foz); C-Area C (Peniche); D-Area D (between Setúbal and Sines); E-Area E (Algarve region); ( $\square$ main cities near the surveyed areas); Wave buoys stations : CSA92D; CSA83D and CSA82D; Currents stations $\square$ : ADCP1, ADCP2, ADCP3, ADCP4, ADCP5, and ADCP6).

Water samples were collected with CTD (conductivity, temperature, depth) profiles being acquired along the water column. For the purpose of this study, data from the superficial layer (2-7 m depth) was selected. For the nutrients analysis, the water samples were filtered using $0.45 \mu \mathrm{m}$ pore size polycarbonate filters and preserved at a temperature below $-18{ }^{\circ} \mathrm{C}$ in high-density polyethylene bottles until subsequent analysis at the Hydrographic Institute (IH) laboratories. Total oxidized nitrogen (also known as nitrate + nitrite, $\left.\mu \mathrm{mol} \mathrm{L}{ }^{-1} ; \mathrm{NO}_{\mathrm{x}}\right)$, nitrites $\left(\mu \mathrm{mol} \mathrm{L}{ }^{-1} ; \mathrm{NO}_{2}\right)$, ammonia $\left(\mu \mathrm{mol} \mathrm{L}{ }^{-1} ; \mathrm{NH}_{3}\right)$, phosphate 
$\left(\mathrm{PO}_{4} ; \mu \mathrm{mol} \mathrm{L}{ }^{-1}\right)$, and silicate $\left(\mu \mathrm{mol} \mathrm{L}{ }^{-1} ; \mathrm{SiO}_{2}\right)$ were analyzed. Nitrates $\left(\mu \mathrm{mol} \mathrm{L}{ }^{-1} ; \mathrm{NO}_{3}\right)$ were estimated by calculating the difference between $\mathrm{NO}_{\mathrm{x}}{ }^{-}$and $\mathrm{NO}_{2}{ }^{-}$. The water samples for chlorophyll $a\left(\mu \mathrm{g} \mathrm{L}^{-1}\right)$ analysis were filtered using $0.45 \mu \mathrm{m}$ pore size mixed cellulose ester filters and the filters were preserved at a temperature below $-18{ }^{\circ} \mathrm{C}$ until subsequent analysis at the $\mathrm{IH}$ laboratories. $\mathrm{pH}$ and dissolved oxygen $\left(\mathrm{mg}-\mathrm{O}_{2} \mathrm{~L}^{-1}\right)$ measurements were performed at the ship's laboratory, while temperature $\left({ }^{\circ} \mathrm{C}\right)$ and salinity data were extracted from the CTD profiles for the desired depths. Water collection was carried out in 265 stations and 249 stations in 2018 and 2019, respectively (Table 1).

Table 1. Number of stations for water collection per area in the 2018 and 2019 field surveys.

\begin{tabular}{ccccccc}
\hline Areas & A & B & C & D & E & Total \\
\hline 2018 & 55 & 65 & 12 & 23 & 110 & 265 \\
\hline 2019 & 45 & 59 & 18 & 22 & 105 & 249 \\
\hline
\end{tabular}

\subsection{Biological and Physico-Chemical Analysis}

The biological and physico-chemical parameters were determined in the $\mathrm{IH}$ laboratories, according to test methods mostly accredited to NP EN ISO/IEC 17025:2005. Quality control was carried out for all tests, including the performance of duplicates (for every batch of 10 samples), blank tests and spiked samples (per day of work), use of certified reference materials CRM), and participation in QUASIMEME (Quality Assurance of Information in Marine Environmental Monitoring) intercalibration exercises. The CRM results were within the uncertainty of the certified materials and the QUASIMEME intercomparison exercises were consistent with satisfactory performance (Z-score $<3$ ). The concentration of nutrients $\left(\mathrm{NO}_{2}, \mathrm{NO}_{\mathrm{x}}, \mathrm{NH}_{3}, \mathrm{PO}_{4}\right.$, and $\left.\mathrm{SiO}_{2}\right)$ was determined by segmented flow analysismolecular absorption spectrometry using a Skalar SANplus Segmented Flow AutoAnalyzer, specifically designed for the analysis of saline samples. $\mathrm{NO}_{2}$ and $\mathrm{NO}_{\mathrm{x}}$ were determined according to Strickland and Parsons [28], $\mathrm{PO}_{4}$ was determined according to Murphy and Riley [29] and $\mathrm{SiO}_{2}$ was determined according to Koroleff [30]. Salinity, $\mathrm{pH}$, dissolved oxygen $\left(\mathrm{mg} \mathrm{L}^{-1}\right)$, and temperature $\left({ }^{\circ} \mathrm{C}\right)$ were determined in-situ using the equipment Guideline Autosal8400B, pH Metrohm 744" and "pH Metrohm 827, Thermo Scientific Orion Star 2135 and IDRONAUT General Oceanics, respectively. Chlorophyll $a$ concentration was determined by molecular absorption spectrometry using the Jeffrey and Humphrey [31] method using a Thermo Scientific Evolution $201 \mathrm{UV}$-Vis spectrometer.

The map of surface temperature (up to $7 \mathrm{~m}$ ) was made using the ArcGIS software for Windows, in the "ArcMap" division, version 10.2.2. This software allows geographic and oceanographic data to be interpolated into high-resolution maps with different interpolation options, where this study used the "Empirical Bayesian Kriging" interpolation method to create the surface temperature maps.

\subsection{Mean Monthly Temperature}

Mean monthly temperature data were collected from the NASA GHRSST (Group for High-Resolution Sea Surface Temperature, Level 4) project platform. This platform collects daily ocean temperature data up to $1 \mathrm{~m}$ depth across the globe. It uses AVHRR (Advanced Very High Resolution Radiometer), AMSR-E (Advanced Microwave Scanning Radiometer), GOES (Geostationary Operational Environmental Satellite), and MODIS (Moderate Resolution Imaging Spectroradiometer) systems (Naval Oceanographic Office, GHTSST Level 4,2008). This platform allows the extraction of oceanographic temperatures every $625 \mathrm{~km}^{2}(25 \times 25 \mathrm{~km})$. The daily temperature values were used to collect and calculate the monthly mean temperature values in 2018 (Figure 2a) and 2019 (Figure 2b) within the boundaries of each area studied. 


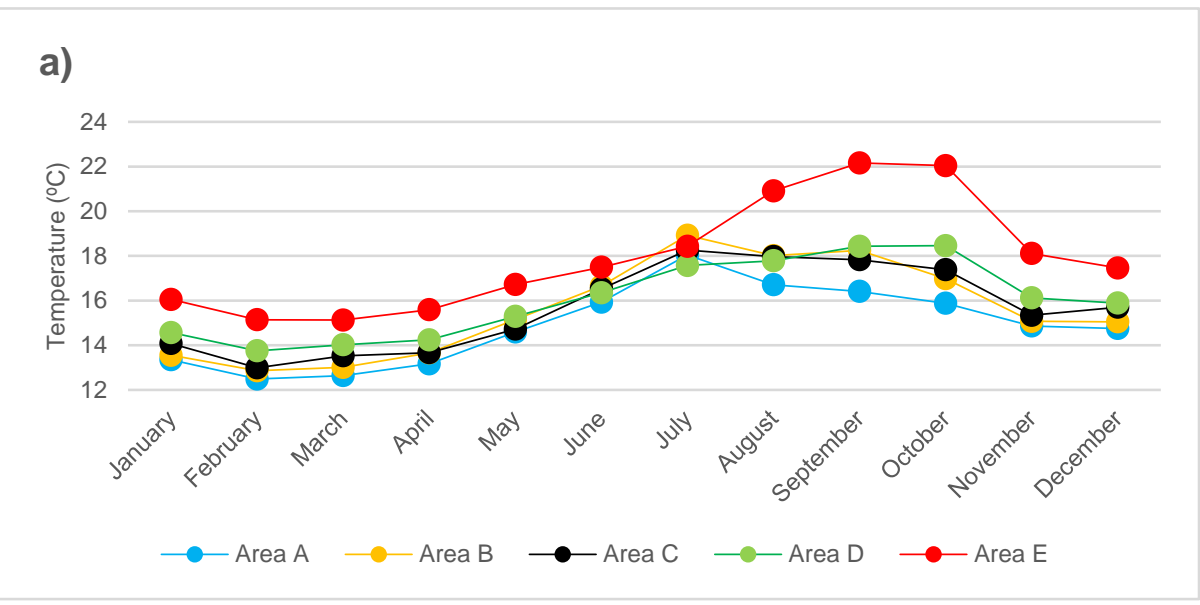

b)

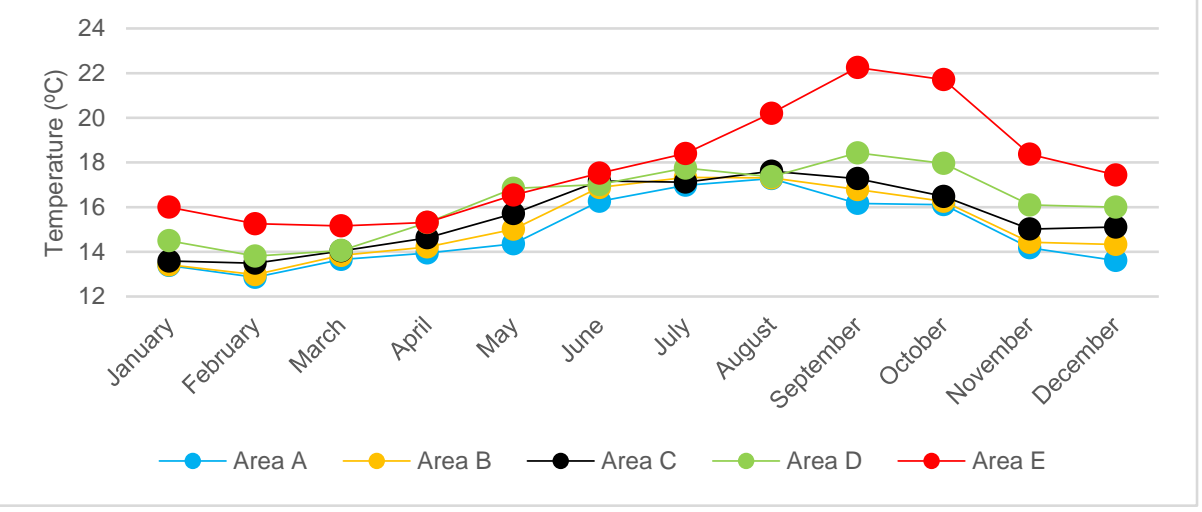

Figure 2. Mean monthly temperature $\left({ }^{\circ} \mathrm{C}\right.$ ) of the water surface (up to $1 \mathrm{~m}$ deep) in the 5 study areas (a) 2018 and (b) 2019 (water temperature data based on satellite reanalysis data).

\subsection{Waves}

Wave data was collected from three moored buoys (Figure 1) managed under protocols between the IH and the "Administração do Porto do Douro e de Leixões" (APDL) and "Administração dos Portos de Sines e do Algarve" S. A. (APS) between the time periods of 1996 and 2019 for Leixões; 1988 and 2019 for Sines and 1986 and 2019 for Faro. The analysis of the Leixões buoy is used to characterize the waves in central and north-western Areas A, B, and C, the Sines buoy to characterize the waves in Area D and the Faro buoy to characterize the waves in Area E.

\subsection{Currents}

In order to study the currents along the water column, several "Acoustic Doppler Current Profiler" (ADCP) of the RD Instruments brand were deployed during the timeframe of the AQUIMAR project, for a minimum period of 3 months at 5-30 m depth between 2018 and 2020. Since Area E covers the entire southern coast of the Algarve, two points were established to cover the area (Figure 1) - one in the western Algarve (Lagos) and one in the eastern Algarve (Olhão). The same method was applied for Area B, where 2 points were defined to collect the data: one point in the north (Aveiro) and the other point in the south (Figueira da Foz). In each of the Areas A and D, one point was set up to represent each location: in Póvoa do Varzim and Comporta, respectively. In Area C it was decided not to place any observation point due to the risk of equipment loss caused by trawling activities. 


\subsection{Species Selection}

A few authors have identified some promising species to be developed in offshore aquaculture as some of them are native and are economically interesting. Among them are fish such as the meagre Argyrosomus regius [32], cod Gadus morhua [33], salmon Salmo salar [34], gilthead sea bream Sparus aurata [35], sea bass Dicentrarchus labrax [36], sardine Sardina pilchardus [37], and greater amberjack Seriola dumerili [38]; mollusks bivalves such as mussel Mytilus edulis [39], scallop Pecten maximus [40], oyster Magallana gigas [41], and clam Ruditapes decussatus [42]; or even macroalgae as Gracilaria gracilis [43], Porphyra umbilicalis [44], and Undaria pinnatifida [45]. A survey of indexed papers in Scopus (published between 1975 and 2021) was carried out with the aim of compiling the optimal growth parameters for these species that can have the potential to be produced in aquaculture offshore or in coastal areas in Portugal. The maximum, minimum, and optimal data of temperature and limiting compounds for fish, bivalve, and macroalgae species are also analyzed and related to the results of the water quality parameters obtained in the AQUIMAR field surveys and thus, the areas with the greatest potential to implement aquaculture for each species are identified.

\subsection{Statistical Analysis and Data Processing}

The concentration of nutrients (ammonia, nitrite, nitrate, silicate, phosphate), chlorophyll $a$, dissolved oxygen, temperature, salinity, $\mathrm{pH}$, and chlorophyll $a$ data were analyzed by two-way ANOVA using IBM SPSS ${ }^{\mathrm{TM}}$ Statistics for Windows, version 23 (IBM Corporation, Armonk, NY, USA). Differences between the means were tested using the Tukey HSD test post hoc. Significant differences were considered when $p<0.05$. Concentrations of ammonia, nitrite, and phosphate below the respective limits of quantification were signaled. The wave height $(\mathrm{Hm} 0)$ data were processed and presented in terms of minimum, maximum, and mean values and predominant wave direction found for each site. Sea currents data were analyzed to determine the absolute maximum intensity and the predominant direction for each analyzed location.

\section{Results}

\subsection{Biological and Physico-Chemical Parameters}

During the field surveys of 2018 and 2019, ammonia, nitrite, and phosphate systematically revealed concentrations below the respective limits of quantification in all areas (Table 2). In both surveys, Area A presented the highest mean concentrations of nitrate (1.27 and $1.8 \mu \mathrm{mol} \mathrm{L}^{-1}$ respectively), while Areas B $\left(0.55\right.$ and $\left.0.75 \mu \mathrm{mol} \mathrm{L}^{-1}\right)$ and $\mathrm{D}(0.53$ and $0.77 \mu \mathrm{mol} \mathrm{L}^{-1}$ ) showed the lowest mean values in both surveys, however, no significant differences were detected $(p>0.05)$. Furthermore, Area A also displayed the highest concentrations of chlorophyll $a$ in both surveys $\left(2.03\right.$ and $\left.5.12 \mu \mathrm{g} \mathrm{L}^{-1}\right)$, whereas Areas E $\left(0.30 \mu \mathrm{g} \mathrm{L}^{-1}\right)$ and $\mathrm{C}\left(1.06 \mu \mathrm{g} \mathrm{L}^{-1}\right)$ presented the lowest mean concentrations in 2018 and 2019 , respectively. Although without statistically significant differences $(p>0.05)$, the area that showed the highest silicate concentrations (3.04 and $2.17 \mu \mathrm{mol} \mathrm{L}^{-1}$ ) was Area $C$ in both surveys, and Areas D and B indicated the lowest concentrations (1.58 and $1.20 \mu \mathrm{mol} \mathrm{L}^{-1}$ ) in 2018 and 2019, respectively. Dissolved oxygen showed statistically significant differences $(p<0.05)$ in area $\mathrm{A}$, with a lower dissolved oxygen value in $2018\left(7.66 \mathrm{mg} \mathrm{L}^{-1}\right)$ than in 2019 $\left(9.23 \mathrm{mg} \mathrm{L}^{-1}\right)$. $\mathrm{pH}$ showed a very homogeneous behavior between areas and surveys while salinity presented significantly higher values in the south. 
Table 2. Mean \pm standard deviation values of ammonia, nitrite, nitrate, chlorophyll $a$, silicate, phosphate, $\mathrm{pH}$, dissolved oxygen, and salinity were determined for the 2018 and 2019 surveys for the surface level ( 2 to $7 \mathrm{~m}$ depth). Values below a determined concentration are the limit of quantification for each parameter analyzed are signaled with the symbol $<$. Note: values sharing a different letter were significantly different $(p<0.05)$ between the area for each year of a field survey; * represents statistically significant differences between the field surveys in the different years $(p<0.05)$.

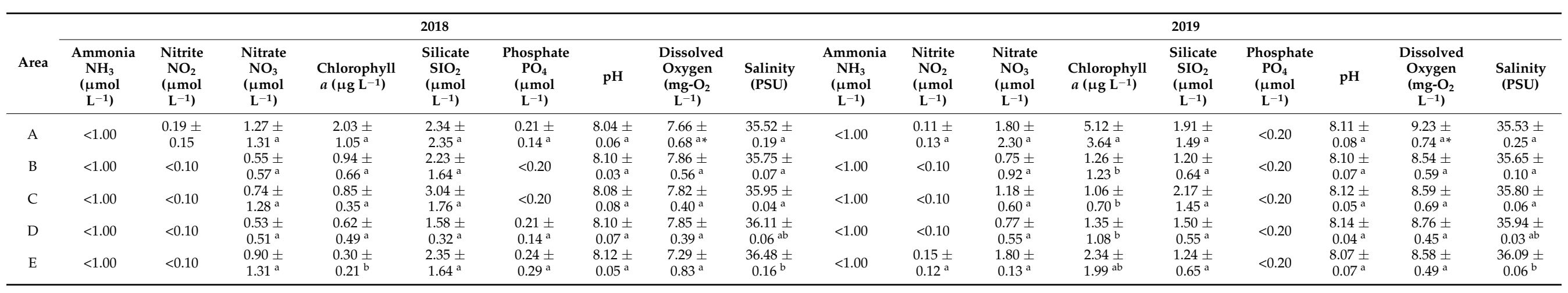


As previously stated, the temperature can be the most important factor to decide the location of offshore and coastal aquaculture implementation and species selection. It can be noticed that the highest temperatures were measured during the 2018 survey (Figure 3). Area E presented the highest surface temperatures and Area A the lowest surface temperatures in both surveys.

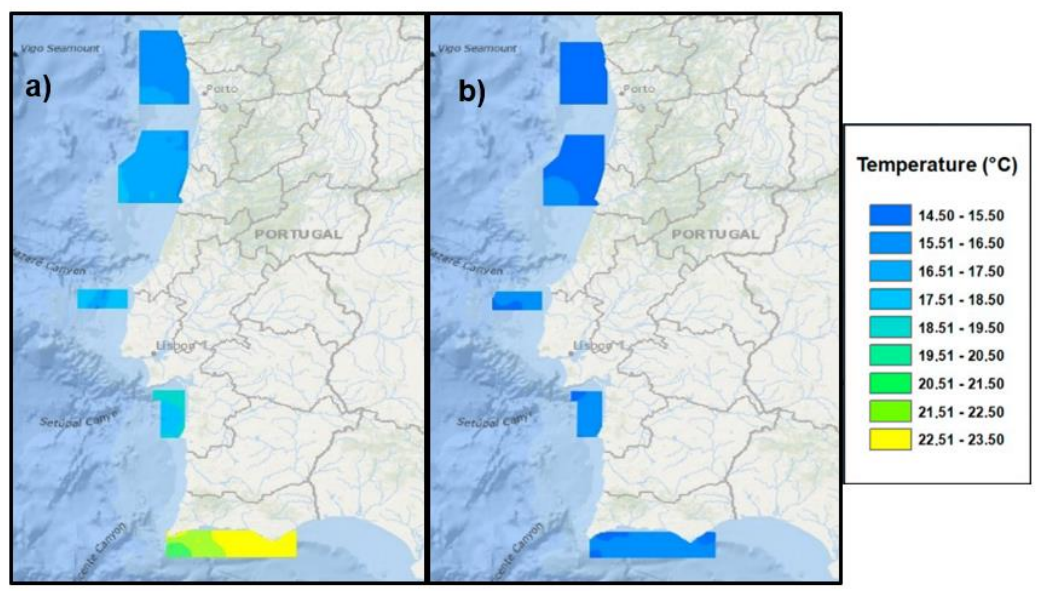

Figure 3. Map of surface temperature $\left({ }^{\circ} \mathrm{C}\right)$ in the 5 study areas of the Portuguese coast in (a) October 2018 and (b) April 2019 surveys.

\subsection{Limit and Optimal Parameters for Production}

The compilation of minimum, maximum, and optimal temperatures to grow the selected species with potential for offshore and coastal aquaculture in Portugal are presented in Tables 3-5. Nutrient levels (ammonia and nitrite) that can compromise the survival and growth performance of fish and bivalves are also presented in Tables 3 and 4 . The most important and common parameter for all groups of species is temperature, although, for bivalves, it is also fundamental to assess the food availability in the terms of phytoplankton, for which chlorophyll $a$ was used as a phytoplankton biomass indicator (Table 4). For macroalgae, the nutrient availability in the form of nitrogen and phosphate was described in Table 5. The $\mathrm{pH}$, dissolved oxygen, and salinity values observed in Table 2 are within the requirements of the species studied and were not considered limiting factors.

Table 3. Minimum, maximum, and optimal temperature $\left({ }^{\circ} \mathrm{C}\right)$ and limits of ammonia $\left(\mu \mathrm{mol} \mathrm{L} \mathrm{L}^{-1}\right)$ and nitrite $\left(\mu \mathrm{mol} \mathrm{L}{ }^{-1}\right)$ tolerated by the selected fish.

\begin{tabular}{|c|c|c|c|c|c|}
\hline \multirow{2}{*}{ Fish } & \multicolumn{3}{|l|}{ Temperature $\left({ }^{\circ} \mathrm{C}\right)$} & \multirow{2}{*}{ Ammonia $\left(\mathrm{NH}_{3}\right)$} & \multirow{2}{*}{ Nitrite $\left(\mathrm{NO}_{2}\right)$} \\
\hline & Minimum & Maximum & Ideal & & \\
\hline $\begin{array}{l}\text { Meagre } \\
\text { (Argyrosomus regius) }\end{array}$ & $\begin{array}{l}13.0^{\circ} \mathrm{C}[29] \\
14.0^{\circ} \mathrm{C}[46]\end{array}$ & $\begin{array}{l}28.0^{\circ} \mathrm{C}[29] \\
26.0^{\circ} \mathrm{C}[46]\end{array}$ & $\begin{array}{l}20.0-21.0{ }^{\circ} \mathrm{C} \\
\text { (Larvae) [29] } \\
26{ }^{\circ} \mathrm{C}[47]\end{array}$ & $\begin{array}{l}\text { Lc } 50 * \\
-41.1 \mu \mathrm{mol} \mathrm{L}-1 \\
(3.0 \pm 0.9 \mathrm{~g} ; 96 \mathrm{~h} ; \\
30 \text { PSU; } 22^{\circ} \mathrm{C} ; \\
\text { pH: 8.2) [48] }\end{array}$ & $\begin{array}{l}\mathrm{Lc} 50 * \\
-849.6 \mu \mathrm{mol} \mathrm{L}-1 \\
(3.2 \pm 0.6 \mathrm{~g} ; 96 \mathrm{~h} ; \\
30 \text { PSU; } 22^{\circ} \mathrm{C} ; \\
\text { pH: 8.0) [49] }\end{array}$ \\
\hline $\begin{array}{l}\text { Atlantic Cod } \\
\text { (Gadus morhua) }\end{array}$ & $\begin{array}{l}-1.5^{\circ} \mathrm{C} \\
{[50]}\end{array}$ & $17.0^{\circ} \mathrm{C}$ (Juvenile) [51] & $\begin{array}{l}7.0^{\circ} \mathrm{C}[51] \\
15.4 \pm 1.1^{\circ} \mathrm{C}[52] \\
8.2 \pm 1.5^{\circ} \mathrm{C}[52] \\
9.0^{\circ} \mathrm{C}[53]\end{array}$ & $\begin{array}{l}>5.9 \mu \mathrm{mol} \mathrm{L}^{-1}- \\
\text { Slow growth of } \\
\text { juveniles, [54] }\end{array}$ & $\begin{array}{l}>20 \mu \mathrm{mol} \mathrm{L}^{-1}- \\
\text { Slow growth } \\
\text { (7.0 } \pm 1.9 \mathrm{~g} ; 96 \text { days; } \\
33 \text { PSU; pH: 8.0) [55] }\end{array}$ \\
\hline $\begin{array}{l}\text { Atlantic Salmon } \\
\text { (Salmo salar) }\end{array}$ & $\begin{array}{l}0.0-7.0^{\circ} \mathrm{C}(\text { Parr }+ \\
\text { smolt) }[56,57] \\
14.0^{\circ} \mathrm{C}[58-60] \\
8.0^{\circ} \mathrm{C} \\
\text { (Post-smolt) }[61,62]\end{array}$ & $\begin{array}{l}22.0-28.0^{\circ} \mathrm{C}(\text { Parr }+ \\
\text { smolt) }[56,57] \\
18.0^{\circ} \mathrm{C}[58-60] \\
12.0^{\circ} \mathrm{C} \\
\text { (Post-smolt) }[61,62]\end{array}$ & $\begin{array}{l}13.0^{\circ} \mathrm{C}[63-65] \\
12.0-18.0^{\circ} \mathrm{C}[66]\end{array}$ & $\begin{array}{l}\text { Lc } 50^{*} \\
-5.34 \mu \mathrm{mol} \mathrm{L}-1 \\
(4.8-9.2 \mathrm{~cm} ; 96 \mathrm{~h} ; \\
12.5^{\circ} \mathrm{C} ; \mathrm{pH}: \\
6.05 ;[67]) \\
>2.06 \mu \mathrm{mol} \mathrm{L}{ }^{-1}- \\
\text { Slow growth } \\
(17.4 \pm 0.1 \mathrm{~g} ; 35 \mathrm{PSU} ; \\
\text { pH: 7.2) [68] }\end{array}$ & $\begin{array}{l}>74 \mu \mathrm{mol} \mathrm{L}^{-1}- \\
\text { Slow growth } \\
\text { (Smolt) [69] }\end{array}$ \\
\hline
\end{tabular}


Table 3. Cont.

\begin{tabular}{|c|c|c|c|c|c|}
\hline \multirow{2}{*}{ Fish } & \multicolumn{3}{|l|}{ Temperature $\left({ }^{\circ} \mathrm{C}\right)$} & \multirow{2}{*}{ Ammonia $\left(\mathrm{NH}_{3}\right)$} & \multirow{2}{*}{ Nitrite $\left(\mathrm{NO}_{2}\right)$} \\
\hline & Minimum & Maximum & Ideal & & \\
\hline $\begin{array}{l}\text { Gilthead bream } \\
\text { (Sparus aurata) }\end{array}$ & $\begin{array}{l}11.0^{\circ} \mathrm{C}[70] \\
11.0-12.0^{\circ} \mathrm{C}[71] \\
13.0^{\circ} \mathrm{C}[72] \\
>12.0^{\circ} \mathrm{C}[73] \\
>12.0^{\circ} \mathrm{C}[74]\end{array}$ & $\begin{array}{l}32.9^{\circ} \mathrm{C}[70] \\
30.0^{\circ} \mathrm{C}[75] \\
30.0^{\circ} \mathrm{C}[74]\end{array}$ & $\begin{array}{l}24.0-26.0^{\circ} \mathrm{C}[76,77] \\
24.0^{\circ} \mathrm{C} \text { (Larvae) [78] } \\
22.0^{\circ} \mathrm{C}[75] \\
23.0^{\circ} \mathrm{C}[73] \\
25.0^{\circ} \mathrm{C}[74]\end{array}$ & $\begin{array}{l}\text { Lc } 50 * \\
-146.8 \mu \mathrm{mol} \mathrm{L}{ }^{-1} \\
(160 \mathrm{~g} ; 96 \mathrm{~h} ; 34 \mathrm{PSU} ; \\
\left.18^{\circ} \mathrm{C} ; \mathrm{pH} 8,1\right)[79] \\
\text { Lc } 50-44.7 \mu \mathrm{mol} \mathrm{L}-1 \\
(1.1 \pm 0.1 \mathrm{~g} ; 96 \mathrm{~h} ; \\
30 \mathrm{PSU} ; \\
\left.20^{\circ} \mathrm{C}\right)[80]\end{array}$ & - \\
\hline $\begin{array}{l}\text { Sea bass } \\
\text { (Dicentrarchus labrax) }\end{array}$ & $\begin{array}{l}5.0^{\circ} \mathrm{C}[81] \\
2.0-3.0^{\circ} \mathrm{C}[77] \\
5.0^{\circ} \mathrm{C}[82] \\
11.0-15.0^{\circ} \mathrm{C} \\
\text { (Larvae) [77] }\end{array}$ & $\begin{array}{l}28.0^{\circ} \mathrm{C}[81] \\
30.0-32.0^{\circ} \mathrm{C} \text { [77] } \\
26.0^{\circ} \mathrm{C} \text { (Larvae) [83] } \\
28.0^{\circ} \mathrm{C}[82] \\
30.0-32.0^{\circ} \mathrm{C} \\
\text { (Larvae) [77] }\end{array}$ & $\begin{array}{l}22.0-24.0^{\circ} \mathrm{C}[81] \\
22.0-25.0^{\circ} \mathrm{C}[77] \\
25.0^{\circ} \mathrm{C}[84] \\
20.0-22.0^{\circ} \mathrm{C} \\
\text { (Larvae) [77] } \\
20.0^{\circ} \mathrm{C}[85]\end{array}$ & $\begin{array}{l}\text { Lc } 50 * \\
\text { — } 99.8 \mu \mathrm{mol} \mathrm{L}{ }^{-1}(11 \mathrm{~g} ; \\
96 \mathrm{~h} ; 37 \text { PSU; } 21.8^{\circ} \mathrm{C} ; \\
\text { pH 8.0) [79] }\end{array}$ & $\begin{array}{l}\text { Lc } 50 * \\
-1035 \mu \mathrm{mol} \mathrm{L}-1 \\
(15 \mathrm{~cm} ; 96 \mathrm{~h} ; 36 \mathrm{PSU} ; \\
23^{\circ} \mathrm{C} ; \mathrm{pH} \\
8.1-8.4)[86]\end{array}$ \\
\hline $\begin{array}{l}\text { Sardine } \\
\text { (Sardina pilchardus) }\end{array}$ & $13.0^{\circ} \mathrm{C}$ (Larvae) [37] & $22.0^{\circ} \mathrm{C}$ (Larvae) [37] & $15.5-17.5^{\circ} \mathrm{C}[87]$ & $\begin{array}{l}\text { Lc } 50 * \\
-43.45 \mu \mathrm{mol} \mathrm{L}{ }^{-1} \\
\text { (Sardinella brasiliensis; } \\
1.04 \pm 0.20 \mathrm{~g} ; 96 \mathrm{~h} ; \\
33.2 \mathrm{PSU} \\
19.2^{\circ} \mathrm{C} \text { ) [88] }\end{array}$ & - \\
\hline $\begin{array}{l}\text { Greater amberjack } \\
\text { (Seriola dumerili) }\end{array}$ & $17.0^{\circ} \mathrm{C}$ (Juvenile) [89] & - & $\begin{array}{l}26.5^{\circ} \mathrm{C} \\
\text { (Seriola lalandi) [90] } \\
26.0^{\circ} \mathrm{C} \text { (Juvenile) [89] }\end{array}$ & - & - \\
\hline
\end{tabular}

- Data not found. * Lc 50-Lethal concentration required to cause mortality in $50 \%$ of the individuals in a test.

Table 4. Minimum, maximum, and optimal temperature $\left({ }^{\circ} \mathrm{C}\right)$ and limits of ammonia $\left(\mu \mathrm{mol} \mathrm{L}{ }^{-1}\right)$ and nitrite $\left(\mu \mathrm{mol} \mathrm{L} \mathrm{L}^{-1}\right)$ tolerated by the bivalves to be produced in aquaculture and data of chlorophyll a $\left(\mu \mathrm{g} \mathrm{L}^{-1}\right)$ or amount of microalgae needed for growth.

\begin{tabular}{|c|c|c|c|c|c|c|}
\hline \multirow{2}{*}{ Bivalves } & \multicolumn{3}{|l|}{ Temperature $\left({ }^{\circ} \mathrm{C}\right)$} & \multirow{2}{*}{ Ammonia $\left(\mathrm{NH}_{3}\right)$} & \multirow{2}{*}{$\begin{array}{l}\text { Nitrite } \\
\left(\mathrm{NO}_{2}\right)\end{array}$} & \multirow{2}{*}{$\begin{array}{l}\text { Phytoplankton } \\
\text { (Chlorophyll } a \text { or } \\
\text { Concentration) }\end{array}$} \\
\hline & Minimum & Maximum & Ideal & & & \\
\hline $\begin{array}{l}\text { Blue mussel } \\
\text { (Mytilus edulis) }\end{array}$ & $5.0^{\circ} \mathrm{C}[91]$ & $28.2^{\circ} \mathrm{C}[91]$ & $\begin{array}{l}13.0-22.0^{\circ} \mathrm{C} \\
\text { (Mytilus } \\
\text { californianus) [92] } \\
15.0-20.0^{\circ} \mathrm{C}[93] \\
11.0-18.0^{\circ} \mathrm{C}[94]\end{array}$ & $\begin{array}{l}\text { Lc } 50 * \\
-1.47 \mu \mathrm{mol} \mathrm{L}^{-1} \\
(22 \pm 2.5 \mathrm{~mm} ; \\
21 \text { days; } 15.9 \pm \\
0.5^{\circ} \mathrm{C} ; \mathrm{pH}: 7.94 \pm \\
0.07 ; 29.7 \pm 0.03 \\
\text { PSU) [94] }\end{array}$ & - & $\begin{array}{l}\text { Min: } 0.5 \mu \mathrm{g} \mathrm{L}^{-1}- \\
0.9 \mu \mathrm{g} \mathrm{L}^{-1} \\
\text { Ideal: } 6.3 \mu \mathrm{g} \mathrm{L}^{-1}- \\
10 \mu \mathrm{g} \mathrm{L}-1 \\
(\text { Chlorophyll } a \text { ) }[95,96]\end{array}$ \\
\hline $\begin{array}{l}\text { Scallop } \\
\text { (Pecten maximus) }\end{array}$ & $\begin{array}{l}4.0^{\circ} \mathrm{C}[97] \\
6.5^{\circ} \mathrm{C}[98] \\
5.0-8.0^{\circ} \mathrm{C}[99]\end{array}$ & $22.9^{\circ} \mathrm{C}[98]$ & $\begin{array}{l}16.0-17.0^{\circ} \mathrm{C}[98] \\
10.0-14.0^{\circ} \mathrm{C}[100]\end{array}$ & - & - & $\begin{array}{l}\text { Fast growth: } \\
300 \mu \mathrm{g} \mathrm{L}^{-1} \text { (Rhodomonas } \\
\text { baltica) [101] }\end{array}$ \\
\hline $\begin{array}{l}\text { Osyter } \\
\text { (Magallana gigas) }\end{array}$ & $8.0-10.0^{\circ} \mathrm{C}[102]$ & $32.0^{\circ} \mathrm{C}[103]$ & $\begin{array}{l}18.0-20.0^{\circ} \mathrm{C} \\
\text { (Magallana } \\
\text { angulata) [104] }\end{array}$ & - & - & $\begin{array}{l}\text { Fast growth: } \\
25 \text { cells/hour/larvae } \\
\text { (Magallana } \\
\text { angulata) [105] }\end{array}$ \\
\hline $\begin{array}{l}\text { Razor clam } \\
\text { (Ruditapes } \\
\text { decussatus) }\end{array}$ & $10.0^{\circ} \mathrm{C}[106]$ & $\begin{array}{l}28.0^{\circ} \mathrm{C} \\
(\text { Larvae D) [106] }\end{array}$ & $\begin{array}{l}20.0 \pm 1.0^{\circ} \mathrm{C} \\
\text { (Nothern region of } \\
\text { the Iberian } \\
\text { peninsula) [107] } \\
22.0 \pm 1.0^{\circ} \mathrm{C} \\
\text { (Southern region of } \\
\text { the Iberian } \\
\text { peninsula) [107] }\end{array}$ & $\begin{array}{l}\text { Slow growth: } \\
99.8 \mu \mathrm{mol} \mathrm{L}^{-1}[108]\end{array}$ & & $\begin{array}{l}\text { Fast growth: } \\
70.000 \text { cells } \mathrm{mL}^{-1} \\
\text { (Isochrysis galbana, } \\
\text { Pavlova lutheri and } \\
\text { Chaetoceros muelleri } \\
(1: 1: 2)) \text { [109] }\end{array}$ \\
\hline
\end{tabular}


Table 5. Minimum, maximum, and optimal temperature $\left({ }^{\circ} \mathrm{C}\right)$, phosphate $\left(\mu \mathrm{mol} \mathrm{L}^{-1}\right)$ and nitrogen $\left(\mu \mathrm{mol} \mathrm{L}{ }^{-1}\right)$ for the production of the selected potential macroalgae species to be produced in aquaculture in Portugal.

\begin{tabular}{|c|c|c|c|c|c|}
\hline \multirow{2}{*}{ Macroalgae } & \multicolumn{3}{|l|}{ Temperature $\left({ }^{\circ} \mathrm{C}\right)$} & \multirow{2}{*}{ Phosphate (P) } & \multirow{2}{*}{$\begin{array}{l}\text { Nitrogen } \\
\text { Compounds (N) }\end{array}$} \\
\hline & Minimum) & Maximum & Ideal & & \\
\hline $\begin{array}{l}\text { Gracilaria } \\
\text { (Gracilaria gracilis) }\end{array}$ & $10.0^{\circ} \mathrm{C}[110]$ & $28.0^{\circ} \mathrm{C}[110]$ & $\begin{array}{l}\text { 18.0-23.0 }{ }^{\circ} \mathrm{C}[110] \\
20-25^{\circ} \mathrm{C} \\
\text { (Gracilaria sp.) [111] } \\
25^{\circ} \mathrm{C} \text { (Gracilaria } \\
\text { verrucos) [112] }\end{array}$ & - & - \\
\hline $\begin{array}{l}\text { Nori } \\
\text { (Porphyra umbilicalis) }\end{array}$ & $\begin{array}{l}3{ }^{\circ} \mathrm{C} \text { (Porphyra } \\
\text { yezoensi) [113] } \\
8{ }^{\circ} \mathrm{C} \text { (Porphyra } \\
\text { haitanensi) [113] }\end{array}$ & $20.0^{\circ} \mathrm{C}[114]$ & $\begin{array}{l}10.0-15.0^{\circ} \mathrm{C}[113] \\
10.0^{\circ} \mathrm{C}[115]\end{array}$ & $\begin{array}{l}\text { Fast growth: } \\
19.50 \mu \mathrm{mol} \mathrm{L}^{-1} \\
{[116]}\end{array}$ & $\begin{array}{l}\text { Fast growth: } \\
35 \mu \mathrm{mol} \mathrm{L}^{-1} \\
\text { (Ammonia) [115] }\end{array}$ \\
\hline $\begin{array}{l}\text { Wakame } \\
\text { (Undaria pinnatifida) }\end{array}$ & $5^{\circ} \mathrm{C}[117]$ & $25.0{ }^{\circ} \mathrm{C}[117]$ & $\begin{array}{l}12.0-13.0^{\circ} \mathrm{C}[118] \\
15.0^{\circ} \mathrm{C}[117]\end{array}$ & - & - \\
\hline
\end{tabular}

- Data not found.

\subsection{Sea State}

The sea state is characterized in Table 6, which shows the minimum, maximum, and mean of the wave height $(\mathrm{Hm} 0)$ and predominant wave direction along the years mentioned in chapter 2.4 in the 5 study areas. It is possible to observe that $\mathrm{Hm} 0$ was lower in the south area (Area E) and higher in the north area (Areas A, B, and C). The predominant wave direction on the west coast of Portugal was Northwest and on the south coast of Portugal, the predominant wave direction was West-Southwest.

Table 6. Minimum, maximum, and mean of the significant wave height $(\mathrm{Hm} 0)(\mathrm{m})$ and predominant wave direction in the areas studied.

\begin{tabular}{ccccc}
\hline Areas & $\begin{array}{c}\text { Hm0 (m) } \\
\text { Minimum }\end{array}$ & $\begin{array}{c}\text { Hm0 (m) } \\
\text { Maximum }\end{array}$ & $\begin{array}{c}\text { Hm0 (m) } \\
\text { Mean }\end{array}$ & $\begin{array}{c}\text { Predominant } \\
\text { Wave Direction }\end{array}$ \\
\hline A, B and C & 0.30 & 9.70 & 2.10 & NW \\
\hline D & 0.28 & 9.79 & 1.72 & NW \\
\hline E & 0.14 & 6.97 & 0.96 & WSW \\
\hline
\end{tabular}

\subsection{Sea Currents}

Taking into consideration the proximity of Areas A and B and the observation points, both these areas were considered as a single area for the purpose of sea currents analysis (Table 7). For this period, the predominant current was South-Southwest with a current intensity reaching $0.50 \mathrm{~m}$ per second. Area D showed great variability in the current direction along the observation period, going from North-Northwest to South-Southwest, with a current intensity reaching $0.36 \mathrm{~m}$ per second. Area E displayed great variability in the current direction as well, ranging from East-Northeast to West-Southwest with a current intensity reaching $0.75 \mathrm{~m}$ per second. The current maximum intensity was observed in depths ranging from 5 to $15 \mathrm{~m}$ and decreased gradually with increasing depth. 
Table 7. Current predominant direction and maximum intensity $\left(\mathrm{m} \mathrm{s}^{-1}\right)$ in the studied areas.

\begin{tabular}{ccc}
\hline & Sea Currents & \\
\hline Areas & $\begin{array}{c}\text { Intensity }\left(\mathbf{m ~ s}^{-\mathbf{1}}\right) \\
\text { Maximum }\end{array}$ & Current Direction \\
\hline A and B & $0.40-0.50(5-15 \mathrm{~m}$ depth $)$ & SSW \\
\hline C & No data & No data \\
\hline D & $0.36(5 \mathrm{~m}$ depth $)$ & NNW-SSE \\
\hline E & $0.75(5 \mathrm{~m}$ depth $)$ & ENE-WSW \\
\hline
\end{tabular}

\section{Discussion}

The choice of locations of national maritime areas destined for aquaculture (aquaculture production areas-APA) in Portugal is questionable and was not always correctly selected from a technical point of view [28]. This helps to explain why aquaculture production in Portugal has not increased significantly in recent years as observed in the statistical data published by INE [2]. The Portuguese Maritime Spatial Plan considers several maritime spaces for aquaculture, however, several areas included in this study were not considered (Areas A, C, and D) and this may be due to the fact that offshore aquaculture requires heavy investment and entails increased risks. In the following sections, we focus on the discussion of the water quality parameters for each of the species selected as potential species for increased seafood production. Then, the oceanographic parameters such as waves, currents, and structures or equipment that can be used are analyzed in an integrated way.

\subsection{Fish}

The growth performance and welfare of farmed fish are highly dependent on water quality parameters and the knowledge of the variable physical-chemical environment is limited in the Portuguese coastal area. In this study, data from October 2018 and April 2019 field surveys showed, as expected, that ammonia and nitrite concentrations are well below the toxic limit for any selected fish species that can be farmed in these marine areas. Similarly, dissolved oxygen, salinity, and $\mathrm{pH}$ levels are within the optimal range for developing marine fish farming [30,119-123]. In general, the data from the field surveys highlight the good quality of the water and its potential for the implementation of new productions. However, the essential parameter that changes the most throughout the five areas studied and that strongly influences the survival, health, welfare, feed intake, food conversion ratio, and growth performance is the temperature [36,124-126]. Since the previously mentioned parameters do not present limiting values for the culture of the selected species, the discussion is mainly focused on temperature values.

\subsubsection{Meagre Argyrosomus regius}

The meagre Argyrosomus regius has a high tolerance to various temperature and salinity values. This characteristic allows the meagre to develop in various habitats, including the Mediterranean, Black Sea, and on the west coast of Europe and Africa [127]. Such versatility allows the meagre to grow in all areas of the Portuguese coast since no temperature value reached the minimum values of $13.0^{\circ} \mathrm{C}$ and the maximum values of $28.0^{\circ} \mathrm{C}$ [32]. However, the area that presents better conditions to produce the meagre is Area $\mathrm{E}$, where temperatures above $20^{\circ} \mathrm{C}$ were observed since the optimal temperature of this species is between $20.0-26.0^{\circ} \mathrm{C}[32,47]$. The mean monthly temperature data displayed temperature values above $20.0^{\circ} \mathrm{C}$ in Area E in August, September, and October and the minimum temperatures values reached $15.0^{\circ} \mathrm{C}$ in February, in both years. Although $15.0^{\circ} \mathrm{C}$ is not the ideal temperature to produce the meagre, this species can withstand these decreases in temperature [128]. In Areas A, B, and C, where the temperature can reach values 
below $13.0^{\circ} \mathrm{C}$, the implementation of offshore or land-based fish farms of the meagre is discouraged, as the growth of this species will be reduced.

\subsubsection{Atlantic Cod Gadus morhua}

Although in this study we have not analyzed temperatures at depths below $7 \mathrm{~m}$, it is expected that the installation of an offshore fish farm of Atlantic cod, Gadus morhua, can only be implemented in the northern region of the country and using submersible cages, which can lead to problems related to feeding and cage maintenance. In October 2018, no area presented the optimal temperatures of $7.0-15.4^{\circ} \mathrm{C}$, pointed out for this species by several authors [50-53]. Although the April 2019 field survey showed optimal temperature values in all areas, the mean monthly temperature data demonstrates that throughout the year, it would not be possible to farm cod. In Area A, temperatures higher than $15.4{ }^{\circ} \mathrm{C}$ were observed during 5 months (June, July, August, September, and October). The other areas also presented temperatures above $15.4^{\circ} \mathrm{C}$ causing constraints related to the cod's welfare, growth performance, and potentially high mortality rates.

\subsubsection{Atlantic Salmon Salmo salar}

Atlantic salmon requires low temperature for optimal growth, and these conditions are only found in the coastal regions of the north and center of Portugal. The field surveys data highlight that only in Areas A, B, and C, the production of this species might be possible. In Areas $\mathrm{D}$ and $\mathrm{E}$, the maximum temperature limits $\left(18.0^{\circ} \mathrm{C}\right)$ are exceeded according to the tolerated temperature values for this species $[58,60,63-66]$. In the year 2018, the area that stands out for salmon growth was Area A, where, only in July, temperatures reached $18.0^{\circ} \mathrm{C}$ according to the mean monthly temperature data. The remaining 11 months were in the range of $12.0-18.0^{\circ} \mathrm{C}$. In the following year, Areas A, B, and C never exceeded the minimum and maximum limits of temperatures supported by Atlantic salmon.

\subsubsection{Gilthead Sea Bream Sparus aurata}

During the two surveys performed, none of the areas studied presented temperatures lower than $13.0^{\circ} \mathrm{C}$ for surface waters. This is the temperature at which several authors suggest that Sparus aurata stops feeding $[69,129]$. Some authors refer that the optimal temperature for gilthead sea bream is between $22.0-26.0^{\circ} \mathrm{C}[74,75,77,130]$. Area E, in October 2018, showed optimal mean temperature values for this species growth $\left(22.5^{\circ} \mathrm{C}\right)$. However, in the April 2019 field survey, a decrease of nearly $7.0^{\circ} \mathrm{C}$, to $15.8^{\circ} \mathrm{C}$, was observed. The mean monthly temperature from the GHRSST project data indicates that Areas A, B, and $\mathrm{C}$ showed temperatures below $13.0^{\circ} \mathrm{C}$ in February 2018, pointing out the difficulties for the gilthead sea bream fish farms in these areas. Areas D (where gilthead sea bream is already produced in cages in Sines) and $\mathrm{E}$ did not show temperatures below $13.0^{\circ} \mathrm{C}$ in 2018, nor in 2019. However, the area that presented temperatures closer to the optimal values for the production was Area $\mathrm{E}$, where this species is already produced in extensive or semi-intensive systems on old salt ponds and in land-based tanks. Nevertheless, it should be noted that in 2019, the highest volume of sea bream produced comes from new production establishments located offshore in this area and in Madeira Island [2].

\subsubsection{Sea Bass Dicentrarchus labrax}

In the two field surveys, no temperature value exceeds the limits tolerable to the rearing of the sea bass Dicentrarchus labrax. These results indicate that it is possible to install sea bass fish farms offshore throughout the Portuguese coast. In fact, sea bass is produced in Portugal mainly in semi-intensive systems, however, production is still very low (882 $\mathrm{mts}$ in 2019) [2]. Several authors [36,77,81,82] indicate that the minimum and maximum temperature limits for sea bass are between 2 and $8{ }^{\circ} \mathrm{C}$ and between 28.0 and $32.0^{\circ} \mathrm{C}$, respectively. However, for optimal growth, only Area E in October 2018, shows the optimal temperatures $\left(20.0-25.0^{\circ} \mathrm{C}\right)$ referred by other authors $[77,81,84,85]$. Looking at the mean monthly temperature data, no month in 2018 and 2019 reached the maximum or 
minimum temperature limits for this species production in the areas studied. However, the growth performance is possibly optimized in Area E where closer to the optimum temperature was observed.

\subsubsection{Sardine Sardinia pilchardus}

The temperature data obtained in the field surveys indicate that it is possible to farm sardine along the Portuguese coast. The minimum and maximum temperatures tolerable by sardine larvae are $13.0^{\circ} \mathrm{C}$ and $22.0^{\circ} \mathrm{C}$, respectively, but larval growth rate was higher for larvae reared at $17^{\circ} \mathrm{C}$ [37]. These temperatures are within the range of temperatures registered in all areas, although another study [84] specified that the optimal temperature is between $15.5^{\circ} \mathrm{C}$ and $17.5^{\circ} \mathrm{C}$. As such, the areas that are outside this limit are Areas D and E, where temperatures were above $17.5^{\circ} \mathrm{C}$ in the 2018 survey. The mean monthly temperature data validates that Area E has 5 months in 2018 and 2019 (July, August, September, October, and November) where temperatures were above the optimal value. The mean monthly temperature data indicates that the other areas had temperatures close to $13{ }^{\circ} \mathrm{C}$ (which will probably affect growth) [37]. However, it should be noted that juvenile sardine maintained in captivity with water circulation in open systems for 1 year at $19.0 \pm 1.0^{\circ} \mathrm{C}$ grew substantially and showed adequate levels of essential fatty acids EPA and DHA for human consumption [131]. It should also be noted that this species is not produced on a commercial scale and its production is still a challenge due to low larval survival rates. Wild sardines were kept in captivity with temperatures between $18.2^{\circ} \mathrm{C}$ and $21.6^{\circ} \mathrm{C}$ and survival rates varied between less than 20 to more than $80 \%$ after four weeks, with most of the mortality occurring in the first days after transport [132]. Further research and development of the rearing technology for this species will be needed before commercial production can be implemented.

\subsubsection{Greater Amberjack Seriola dumerili}

The greater amberjack requires high temperature to grow, and these conditions can only be observed in the Algarve coast (Area E) or in the Portuguese islands such as São Miguel Island in the Azores archipelago, where cage production already exists. Fish meal substitution in the diet was possible for this species for long periods without affecting growth with water temperature maintained at $21.5 \pm 2.4^{\circ} \mathrm{C}$ [133]. The greater amberjack needs an increase of temperature from $19.0^{\circ} \mathrm{C}$ to $24.0^{\circ} \mathrm{C}$ to spawn [134] so, for hatchery implementation, Area $\mathrm{E}$ is the best choice. Areas A, B, and C are not recommended for greater amberjack production. Area $\mathrm{D}$ comes close to $19.0^{\circ} \mathrm{C}$ during the summer months but temperatures can reach $14.0^{\circ} \mathrm{C}$ during the winter months. Although Area $\mathrm{E}$ is the most suitable area to introduce fish farms for this species, the maximum temperature registered in the field surveys was $22.0^{\circ} \mathrm{C}$, nevertheless, this area displays the highest temperatures from all areas studied.

\subsection{Bivalves}

The field surveys highlighted the most promising sites to produce bivalves on the Portuguese coast, where the key parameters like temperature, chlorophyll $a$, and silicate are discussed. This last parameter is not directly related to the concentration of diatoms (they have a silicate frustule and are filtered by bivalves) in the water, however, it indicates the areas that have the highest concentrations of silicate (and possibly diatoms) [135] that could be beneficial for shellfish farms [136]. Dissolved oxygen, salinity, and $\mathrm{pH}$ are in the optimal ranges for the studied species and the concentration of toxic parameters such as ammonia and nitrite were below toxic limits.

\subsubsection{Mussel Mytilus edulis}

Focusing on field surveys data, blue mussel growth can be compromised in Area E, as this mussel has an optimal temperature range of $10.0-20.0{ }^{\circ} \mathrm{C}$ [92-94], and this area showed a mean temperature of $22.5^{\circ} \mathrm{C}$ in October 2018. However, currently, it is in this 
area where most of the mussel farms in extensive offshore systems take place [2]. The mean monthly temperature data highlights that beneficial conditions exist in all studied areas except for 3 months (August, September, and October) in Area E in both years, 2018 and 2019, where temperatures recorded were above $20^{\circ} \mathrm{C}$. Observing the chlorophyll $a$ data and considering that the site selection should match, as much as possible, with the physiological needs of mussels to reach a commercial size in the shortest possible period, the area approaching the ideal concentration of $6.3 \mu \mathrm{g} \mathrm{L}^{-1}$ referenced by [95] was Area A, with mean concentrations of $2.03 \mu \mathrm{g} \mathrm{L}^{-1}$ in October 2018 and $5.12 \mu \mathrm{g} \mathrm{L}^{-1}$ in April 2019. However, it should be considered that the oceanographic conditions in this area are not the most suitable for the implementation of offshore longlines. Regarding silicate data, the observed values are relatively low in all areas. The area that showed the highest mean silicate concentrations was Area $C$ with $3.04 \mu \mathrm{mol} \mathrm{L}^{-1}$ and $2.17 \mu \mathrm{mol} \mathrm{L}^{-1}$ in the October 2018 and April 2019 field surveys, respectively, but once again it should be noted that sea agitation can compromise offshore cultivation.

\subsubsection{Scallop Pecten maximus}

All areas in the April 2019 field survey present ideal conditions to implement scallop production. However, only Area A shows optimal temperature values $\left(10-17^{\circ} \mathrm{C}\right)$ in the October 2018 field survey, according to the reference temperature $[97,98]$ and with minimum temperature limits of $4{ }^{\circ} \mathrm{C}$ [97] and maximum temperature of $22.9^{\circ} \mathrm{C}$ [98]. The mean monthly temperature data indicates that only in July 2018 and August 2019, the temperature exceeded $17.0^{\circ} \mathrm{C}$ in Area A. Area E showed 7 months with a temperature above $17.0^{\circ} \mathrm{C}$ in 2018 and 2019 (from June to December), where growth will certainly be reduced although it may not cause mortality. Scallop achieved faster growth with a microalgae concentration of $300 \mu \mathrm{g} \mathrm{L}^{-1}$ (Rhodomonas baltica) in experimental trials [101]. It is worth mentioning that Area A showed a higher chlorophyll $a$ mean concentration but was still far below the values described in the trials. In terms of silicate concentration, Area A exhibits a mean concentration of $3.04 \mu \mathrm{mol} \mathrm{L}-1$ in October 2018 and $2.17 \mu \mathrm{mol} \mathrm{L}^{-1}$ in April 2019 field surveys, which corresponds to the second area with the highest silicate concentrations behind Area $C$ which may indicate that the water from these locations could be the most suitable for the production of this species.

\subsubsection{Oyster Magallana gigas}

Wild stocks of Magallana gigas already exist from Norway to southern Portugal [137]. Currently, oyster production is performed mainly in Portuguese estuaries and basins such as the Ria de Aveiro and the Ria Formosa. Magallana gigas is also already produced, together with Magallana angulata, in the Sado estuary [103]. An older study [138] suggests that under ideal conditions and with high food availability, maximum growth for Magallana gigas might be achieved at temperatures approaching $20.0^{\circ} \mathrm{C}$. The field survey of 2018 showed one area where this temperature range is noticeable, namely Area $\mathrm{D}\left(18.6^{\circ} \mathrm{C}\right.$; mean). In the 2019 field survey, there is no area that presents the optimal temperature for this species farm, however, with minimum limits of $8.0-10.0^{\circ} \mathrm{C}$ [102] and maximum limits of $28.0^{\circ} \mathrm{C}$ [103], it is possible to implement oyster farms throughout the Portuguese coast, offshore or landbased. Analysing the chlorophyll $a$ concentration data, the three Areas B, D, and E present beneficial conditions to develop the production of Magallana gigas. This species is already produced offshore in Area E, but the installation of oyster farms in new sites should always be carried out after pilot studies to ensure that the chosen site provides adequate conditions for survival and growth.

\subsubsection{Razor Clam Ruditapes decussatus}

The razor clam has a range of optimal temperatures depending on its geographical origin [107]. The populations of this species exhibit optimal spawning temperatures of $20.0 \pm 1.0^{\circ} \mathrm{C}$ in the north of the Iberian Peninsula and $22.0 \pm 1.0{ }^{\circ} \mathrm{C}$ in the south of the Iberian Peninsula [107]. Usually, clams are produced in onshore nurseries and buried in 
the sediment, however, its offshore production has been studied and recently a hatchery that intends to perform the growth of this species offshore was established and in the growing phase on the southern coast (Area E). The 2018 field survey indicates that the ideal temperature to produce razor clam is only verified in Area $\mathrm{E}$, where the temperature reached $22.5^{\circ} \mathrm{C}$ (mean). In the 2019 field survey, no area presented optimal conditions to implement an offshore clam farm. However, with minimum temperature limits of $8.0^{\circ} \mathrm{C}$ and maximum limits of $28.0^{\circ} \mathrm{C}$ [106], all areas are within these values. The chlorophyll $a$ concentration in Area E was low when compared to the other areas in the 2018 field survey. However, in the 2019 field survey, Area E was the second area with the highest chlorophyll $a$ concentration $\left(2.34 \mu \mathrm{g} \mathrm{L}^{-1}\right.$; mean).

\subsection{Macroalgae}

In Portugal, the production of macroalgae is almost non-existent, with only a landbased company producing it, but several studies carried out in the Aveiro area, point out the potential of seaweeds to remove nitrogen from the water of a fish farm and to contribute to the creation of new jobs [139]. Essential parameters for macroalgae growth, such as nitrate and phosphate concentration presented stable values with no significant differences in the Portuguese coast. The concentration of ammonia and nitrite were below the limit of quantification. Dissolved oxygen and $\mathrm{pH}$ parameters are not considered to be limiting factors, are within the limits for the studied macroalgae implementation, and, therefore, only phosphate, nitrate, and temperature values are discussed.

\subsubsection{Gracilaria gracilis}

Areas D and E presented the optimal temperatures $\left(18.0-23.0^{\circ} \mathrm{C}\right)$ for Gracilaria sp. rearing [107-109,140]. However, with a maximum temperature limit of $28.0^{\circ} \mathrm{C}$ and a minimum temperature of $10.0^{\circ} \mathrm{C}$ [110], this species can be found along the Portuguese coast. In the field surveys, no area exceeded the temperature limits tolerable by this species. Along with temperature, growth needs to be enhanced with a high concentration of nutrients, where Areas A and E stand out in the concentrations of nitrate and phosphate. The highest nitrate concentrations were observed in Area A and E in the April 2019 survey with $1.80 \mu \mathrm{mol} \mathrm{L}^{-1}$ (mean) and the areas with the highest mean phosphate concentration were Area A and D with $0.21 \mu \mathrm{mol} \mathrm{L}^{-1}$ and Area E with $0.24 \mu \mathrm{mol} \mathrm{L}{ }^{-1}$. In addition to Area $\mathrm{E}$ having the highest nitrate concentrations, the mean monthly temperature data reinforces that this area has 5 months of the year (July and November in 2018 and 2019) with optimal temperatures $\left(18.0-23.0^{\circ} \mathrm{C}\right)$ to farm these macroalgae.

\subsubsection{Porphyra umbilicalis}

Nori is one of the most cost-effective and advantageous macroalgae to produce. This species can reach the commercial size in 45 days [113]. With optimal temperatures of $10.0-15.0^{\circ} \mathrm{C}[113,115,141]$, the most adequate sites for the implementation of this species production are located in the north and center of the country. In the field surveys, the only area that approaches the optimal temperature values for this species farm was Area A with $14.6^{\circ} \mathrm{C}$ (mean) in April 2019 but with $16.1^{\circ} \mathrm{C}$ (mean) in October 2018. The remaining areas exceed $15.0^{\circ} \mathrm{C}$ in both field surveys, however, with a minimum limit of $8.0^{\circ} \mathrm{C}$ [113] and a maximum limit of $20.0^{\circ} \mathrm{C}$ [114], only Areas D and E are not adequate for production. Mean monthly temperature data indicates that Area A has the highest number of months with optimal temperatures of $10.0-15.0^{\circ} \mathrm{C}$, where only in the summer months (June, July, and August) and autumn (September and October), temperatures exceeded $15.0^{\circ} \mathrm{C}$ in both 2018 and 2019. In terms of nutrients, Area A showed the highest nitrate concentration and the second-highest phosphate concentration in the October 2018 survey. In the April 2019 survey, Area A and E were the areas with the highest nitrate concentration as previously mentioned, but the mean phosphate concentration was below the limit of quantification $\left(<0.20 \mu \mathrm{mol} \mathrm{L}^{-1}\right)$. It should be highlighted that the potential of this species to be farmed in integrated multitrophic aquaculture (IMTA) was observed [142]. 


\subsubsection{Undaria pinnatifida}

Literature references indicate that the optimum temperature of wakame Undaria pinnatifida is between $12.0-15.0^{\circ} \mathrm{C}[117,118]$. The only area that shows values within this range is Area A in the April 2019 field survey with temperatures of $14.6{ }^{\circ} \mathrm{C}$ (mean). However, this macroalga can be found throughout the Portuguese coast, since it presents temperature limits above $5.0^{\circ} \mathrm{C}$ and below $25.0^{\circ} \mathrm{C}$ [117]. This macroalga has a high capacity to adapt to temperature, depending on its geographical origin, but some authors $[143,144]$ point out that this species tolerates temperature variations but in the long term, natural selection reduces the population. The mean monthly temperature data indicates that the area that has more months with optimal temperatures is Area A between the months of November to May in both studied years. There is no comparable data for nitrogen and phosphate requirements for this macroalgae.

\subsection{Waves, Currents, and Equipment}

Offshore aquaculture presents significant technical challenges in the design, testing, and construction of systems, such as cages and longlines, and there are also many biological, regulatory, social, and economic problems to be solved [145]. The net cages have innumerable factors that require deep analysis to ensure the safety of production. These factors range from the cage structure itself and deployment depth; the location and weight of the anchors; the ropes attached to the cage; the drag forces applied on the structure by currents and waves; backup plans if the anchors get dragged on the sea floor; ropes entanglement; uncommon sea conditions that may damage the materials, such as storms [146-148]. Light intensity, the availability of dissolved oxygen, rearing density and food supply capacity should also be considered for the survival and welfare of the species produced in submerged cages $[59,149,150]$. Nevertheless, aquaculture cages had rapidly developed in the last decades [148] and can cope with these factors to a certain degree. For instance, the authors [146-148] studied the impact of currents and waves in aquacultures cages. It was observed by [146] that drag forces are dependent on the cage size and system used, where sea currents from $0.2 \mathrm{~m} \mathrm{~s}^{-1}$ to $0.5 \mathrm{~m} \mathrm{~s}^{-1}$ had a proportional increase on the lift force. Compared to the results of this study, Area E had currents velocities that reached $0.75 \mathrm{~m} \mathrm{~s}^{-1}$, indicating that production in cages in this location has to be equipped and prepared to withstand greater lift forces. The results of [147] were inconclusive regarding the waves and currents on the aquaculture cage system used. Although, some results had significant differences, such as the mooring from the cage system not being affected by waves, neither the currents nor the fine numerical mesh from the net suffered any damage when the current velocity reached $0.3 \mathrm{~m} \mathrm{~s}^{-1}$. Since every studied area had a current velocity that exceeded $0.3 \mathrm{~m} \mathrm{~s}^{-1}$, using a larger mesh in these areas would reduce the drag from the waves and currents. In case of an emergency, [148] set an experiment where the mooring system failed, and the cage was subjected to waves and currents. The conditions of this experiment were quite extreme, where the significant wave height reached $6 \mathrm{~m}$ and the current velocity reached $2 \mathrm{~m} \mathrm{~s}^{-1}$. The experiment concluded that, for these conditions, when the mooring system failed, the cage system was subjected to far greater tension, but it stabilized after a while. If combined with an anchor failure as well, the whole aquaculture system becomes unfit for the sea. All studied areas had significant wave heights that exceeded $6 \mathrm{~m}$. According to [119], until further technological solutions allow offshore aquaculture to be developed, the coastal modality is a more pragmatic option for the North Region (Area A) in Portugal. Area E comes close to the wave height studied by [148] with a significant height of $6.97 \mathrm{~m}$. In this area, if the anchor system does not fail, the aquaculture production system should endure storm conditions, and if the aquaculture cage can be successfully placed, other variables need to be added for the biological necessities of the selected species. For example, [59] mention that the Atlantic salmon behaves differently in no light conditions, which results in sub-optimal higher densities (in high-density stocks) but the placement of artificial lights in $15 \mathrm{~m}$ depth cages resulted in a lower density. The study of $[149,150]$ identified that Atlantic salmon in submerged cages swam 1.6 times faster 
than nearer the surface (submerged cages at $3 \mathrm{~m}$ depth). For bivalves and macroalgae, the assessment needs to be reformed, as they need different aquaculture structures such as longlines and have different biological patterns and requirements, the Mytilus galloprovincialis can be grown in longlines on the south coast of Portugal (Area E) from depths between 3 and $15 \mathrm{~m}$ with no significant differences in growth and fatty acid composition [151].

\section{Conclusions}

The results obtained in this study demonstrate the possibility of increasing offshore production on the Portuguese coast. However, more studies are needed taking into consideration the systems and structures available on the market that can withstand the oceanographic conditions of each location. For fish farming, the temperature is the main parameter influencing the survival and growth, since ammonia and nitrite concentrations data were low, and all selected species tolerate the variations observed in dissolved oxygen, salinity, and $\mathrm{pH}$. For species requiring lower temperatures, such as the Atlantic cod, the production is compromised since, at the surface level, the temperature is too high to produce this species. The Atlantic salmon requires lower temperatures and can be considered to be produced in Areas A, B, and C. For species that need warmer temperatures, Area $\mathrm{E}$ has been demonstrated to be adequate to produce gilthead sea bream, sea bass, meagre, and the greater amberjack. For bivalves, the concentration of chlorophyll $a$ plays an important role to determine the best location to implement new structures. The blue mussel can grow in a variety of temperatures, but without looking at the oceanographic conditions, Area A had the highest concentration of chlorophyll $a$ which would benefit its growth performance and reduce the rearing period. The same applies to the scallop, where the lower temperatures and high concentration of chlorophyll $a$ would likely benefit this species. For the oyster, due to specific water temperatures, Area D is the best choice to allow the production of this species and area $\mathrm{E}$ offers a warmer temperature and a sufficient concentration of chlorophyll $a$. Area A seems adequate to implement nori and wakame coastal productions and Area E appears suitable for the production of Gracilaria gracilis. Looking at the oceanographic conditions, the more promising Area is $\mathrm{E}$ as it presents smaller wave heights. However, higher current velocities were observed in Area E. The drag from the currents can be mitigated using a net with a larger mesh size and structures that reduce the possibility of current dragging. The implementation of aquacultures in harsh open sea conditions seems possible, and thus, offshore and coastal aquaculture in Portugal shows potential, but the implementation of new structures must be preceded by dedicated studies that consider the type of structure and the specific location.

Author Contributions: Conceptualization, C.P. and A.P.; methodology, M.M., C.B., N.Z., A.C.B. and R.E.; writing—original draft preparation, M.M.; writing—review and editing, M.M., A.P., A.C.B. and C.P.; supervision, A.P. and C.P. All authors have read and agreed to the published version of the manuscript.

Funding: This study had the financial support of Operational Programme MAR2020 through the project MAR-02.01.01-FEAMP-0107 "AQUIMAR-Marine knowledge supporting aquaculture", and the support of Fundação para a Ciência e Tecnologia (FCT), through the strategic project UIDB/04292/2020 granted to MARE-Marine and Environmental Sciences Centre. AP and ACB were supported through the Scientific Employment Stimulus Programmes (CEECINST/00051/2018 and CEECIND/00095/2017, respectively).

Data Availability Statement: The data presented in this study are available on request from the corresponding author A.P. upon reasonable request.

Conflicts of Interest: The authors declare no conflict of interest. The funders had no role in the design of the study; in the collection, analyses, or interpretation of data; in the writing of the manuscript, or in the decision to publish the results. 


\section{References}

1. Food and Agriculture Organization of the United Nations. The State of World Fisheries and Aquaculture; Food and Agriculture Organization of the United Nations: Rome, Italy, 2020; pp. 21-36.

2. Instituto Nacional de Estatística. Estatística da Pesca: 2020; INE: Lisbon, Portugal, 2021. Available online: https://www.ine.pt/ xurl/pub/280980980 (accessed on 12 December 2021).

3. Santos, P.M.; Albano, A.; Raposo, A.; Ferreira, S.M.F.; Costa, J.L.; Pombo, A. The effect of temperature on somatic and gonadal development of the sea urchin Paracentrotus lividus (Lamarck, 1816). Aquaculture 2020, 528, 735487. [CrossRef]

4. Lourenço, S.; Cunha, B.; Raposo, A.; Neves, M.; Santos, P.M.; Gomes, A.S.; Tecelão, C.; Ferreira, S.M.F.; Baptista, T.; Gonçalves, S.C.; et al. Somatic growth and gonadal development of juvenile Paracentrotus lividus (Lamarck, 1816) fed with diets of different ingredient sources. Aquaculture 2021, 539, 736589. [CrossRef]

5. Venâncio, E.; Félix, P.; Brito, A.C.; Sousa, J.; Silva, F.A.; Simões, T.; Narciso, L.; Amorim, A.; Dâmaso, L.; Pombo, A. Do broodstock diets influence viability and larval development of Holothuria mammata? Aquaculture 2021, 536, 736431. [CrossRef]

6. Jansen, P.A.; Grøntvedt, R.; Tarpai, A.; Helgesen, K.O.; Horsberg, E. Surveillance of the Sensitivity towards Antiparasitic Bath-Treatments in the Salmon Louse (Lepeophteirus salmonis). PLoS ONE 2016, 11, e0149006. [CrossRef] [PubMed]

7. Gentry, R.R.; Froehlich, H.E.; Grimm, D.; Kareiva, P.; Parke, M.; Rust, M.; Halpern, B.S. Mapping the global potential for marine aquaculture. Nat. Ecol. Evol. 2017, 1, 1317-1324. [CrossRef] [PubMed]

8. Thomas, L.R.; Clavelle, T.; Klinger, D.H.; Lester, S.E. The ecological and economic potential for offshore mariculture in the Caribbean. Nat. Sustain. 2019, 68, 219-225. [CrossRef]

9. Primavera, H. Overcoming the impacts of aquaculture on the coastal zone. Ocean Coast. Manag. 2006, 49, 531-545. [CrossRef]

10. McKindsey, C.W.; Thetmeyer, H.; Landry, T.; Silvert, W. Review of recent carrying capacity models for bivalve culture and recommendations for research and management. Aquaculture 2006, 261, 451-462. [CrossRef]

11. Boyd, C.E.; Pillai, V. Water quality management in aquaculture. CMFRI Spec. Publ. 1985, 22, 44.

12. Instituto Nacional de Estatística. Estatística da Pesca: 2019; INE: Lisbon, Portugal, 2020. Available online: https:/ /www.ine.pt/ xportal $/$ xmain?xpid=INE\&xpgid=ine_publicacoes\&PUBLICACOESpub_boui=435690295\&PUBLICACOESmodo=2 (accessed on 27 December 2021).

13. Ryan, J. Farming the Deep Blue; Irish Sea Fisheries Board (BIM) and Irish Marine Institute: Dublin, Ireland, 2004.

14. Debnath, D.; Pal, A.K.; Sahu, N.P.; Baruah, K.; Yengkokpam, S.; Das, T.; Manush, S.M. Thermal tolerance and metabolic activity of yellowtail catfish Pangasius pangasius (Hamilton) advanced fingerlings with emphasis on their culture potential. Aquaculture 2006, 258, 606-610. [CrossRef]

15. Sakamoto, K.; Miyazaki, A.; Taniguchi, N. Thermal tolerance traits of redfin velvetfish Paracentropogon rubripinnis evaluated using their caudal fin cells. Aquaculture 2010, 308, 124-127. [CrossRef]

16. Person-Le Ruyet, J.; Buchet, V.; Vincent, B.; Le Delliou, H.; Quéméner, L. Effects of temperature on the growth of pollack (Pollachius pollachius) juveniles. Aquaculture 2006, 251, 340-345. [CrossRef]

17. Deane, E.E.; Woo, N. Modulation of fish growth hormone levels by salinity, temperature, pollutants and aquaculture related stress: A review. Rev. Fish Biol. Fish. 2009, 19, 97-120. [CrossRef]

18. Oliveira, J.; Castilho, F.; Cunha, A.; Pereira, M.J. Bivalve Harvesting and Production in Portugal: An Overview. J. Shellfish Res. 2013, 32, 911-924.

19. Venugopal, V.; Gopakumar, K. Shellfish: Nutritive Value, Health Benefits, and Consumer Safety. Compr. Rev. Food Sci. Food Saf. 2017, 16, 1219-1242. [CrossRef] [PubMed]

20. Cherifi, H.; Chebil, L.; Sadok, S. Nutritional value of the Tunisian mussel Mytilus galloprovincialis with a special emphasis on lipid quality. Food Chem. 2018, 268, 307-314. [CrossRef]

21. Shumway, S.E.; Davis, C.; Downey, R.; Karney, R.; Kraeuter, J.; Parsons, J.; Rheault, R.; Wikfors, G. Shellfish aquaculture-in praise of sustainable economies and environments. World Aquac. 2003, 34, 15-17.

22. Klinger, D.; Naylor, R. Searching for solutions in aquaculture: Charting a sustainable course. Annu. Rev. Environ. Resour. 2012, 37, 247-276. [CrossRef]

23. Bostock, J.; Lane, A.; Hough, C.; Yamamoto, K. An assessment of the economic contribution of EU aquaculture production and the influence of policies for its sustainable development. Aquac. Int. 2016, 24, 699-733. [CrossRef]

24. Mare, D. Study on Deepening Understanding of Potential Blue Growth in the EU Member States on Europe's Atlantic Arc; DG Maritime Affairs and Fisheries: Rotterdam, The Netherlands; Brussels, Belgium, 2014.

25. Makkar, H.; Tran, G.; Heuzé, V.; Giger-Reverdin, S.; Lessire, M.; Lebas, F.; Ankers, P. Seaweeds for livestock diets: A review. Anim. Feed Sci. Technol. 2014, 212, 1-17. [CrossRef]

26. Bleakley, S.; Hayes, S. Algal proteins: Extraction, application, and challenges concerning production. Foods 2017, 6, 33. [CrossRef] [PubMed]

27. Hurd, C.L. Shaken and stirred: The fundamental role of water motion in resource acquisition and seaweed productivity. Perspect. Phycol. 2017, 4, 73-81. [CrossRef]

28. Strickland, J.D.H.; Parsons, T.R. A Practical Handbook of Seawater Analysis; Fisheries Research Board of Canada: Ottawa, ON, Canada, 1972.

29. Murphy, J.; Riley, J.P. A Modified Single Solution Method for the Determination of Phosphate in Natural Waters. Anal. Chim. Acta 1962, 27, 31-36. [CrossRef] 
30. Koroleff, F. Determination of ammonia. In Methods of Seawater Analysis; Grasshoff, K., Ed.; Verlag Chemie: New York, NY, USA, 1976; pp. 126-158.

31. Jeffrey, S.W.; Humphrey, G.F. New spectrophotometric equations for determining chlorophylls a, b, c1 and c2 in higher plants, algae and natural phytoplankton. Biochem. Physiol. Pflanzen. 1975, 167, 191-194. [CrossRef]

32. Duncan, J.; Estévez, A.; Fernández-Palacios, H.; Gairin, I.; Hernández-Cruz, M.; Roo, J.; Schuchardt, D.; Vallés, R. Aquaculture production of meagre (Argyrosomus regius): Hatchery techniques, ongrowing and market. In Advances in Aquaculture Hatchery Technology; Allan, G., Burnell, G., Eds.; Woodhead Publishing: Cambridge, UK, 2013; pp. 519-541.

33. Badiola, M.; Albaum, B.; Curtin, R.; Gartzia, I.; Mendiola, D. Land based on-growing of Atlantic cod (Gadus morhua) using Recirculating Aquaculture Systems: A case study from the Basque region (Northern Spain). Aquaculture 2017, 468, 428-441. [CrossRef]

34. Sikveland, M.; Zhang, D. Determinants of capital structure in the Norwegian salmon aquaculture industry. Mar. Policy 2020, 119, 104061. [CrossRef]

35. Føre, M.; Frank, K.; Norton, T.; Svendsen, E.; Alfredsen, J.; Dempster, T.; Berckmans, D. Precision fish farming: A new framework to improve production in aquaculture. Biosyst. Eng. 2018, 173, 176-193. [CrossRef]

36. Islam, M.J.; Kunzmann, A.; Bögner, M.; Meyer, A.; Thiele, R.; James, M. Metabolic and molecular stress responses of European seabass, Dicentrarchus labrax at low and high temperature extremes. Ecol. Indic. 2020, 112, 106118. [CrossRef]

37. Garrido, S.; Cristóvão, A.; Caldeira, C.; Ben-Hamadou, R.; Baylina, N.; Batista, H.; Saiz, E.; Peck, M.A.; Ré, P.; Santos, A.M.P. Effect of temperature on the growth, survival, development and foraging behaviour of Sardina pilchardus larvae. Mar. Ecol. Progr. Ser. 2016, 559, 131-145. [CrossRef]

38. Sicuro, B.; Umberto Luzzana, U. The State of Seriola spp. Other Than Yellowtail (S. quinqueradiata) Farming in the World. Rev. Fish. Sci. Aquac. 2016, 24, 314-325. [CrossRef]

39. Azpeitia, K.; Rios, Y.; Garcia, I.; Pagaldai, J.; Mendiola, D. A sensory and nutritional validation of open ocean mussels (Mytilus galloprovincialis Lmk.) cultured in SE Bay of Biscay (Basque Country) compared to their commercial counterparts from Galician Rias (Spain). Int. Aquat. Res. 2017, 9, 89-106. [CrossRef]

40. Ansell, A.D.; Dao, J.; Mason, J. Three European scallops: Pecten maximus, Chlamys opercularis and C. (Chlamys) varia. In Scallops: Biology, Ecology and Aquaculture; Shumway, S.E., Parsons, G.J., Eds.; Elsevier: Amsterdam, The Netherlands, 1991; pp. 715-751.

41. Wang, Y.K.; He, H.L.; Wang, G.F.; Wu, H.; Zhou, B.C.; Chen, X.L.; Zhang, Y.Z. Oyster (Magallana gigas) hydrolysates produced on a plant scale have antitumor activity and immunostimulating effects in BALB/c mice. Mar. Drugs 2010, 8, 255-268. [CrossRef] [PubMed]

42. Ojea, J.; Pazos, A.P.; Martínez, D.; Novoa, S.; García-Martínez, P.; Sánchez, J.L.; Abad, M. Effects of temperature regime on broodstock conditioning of Ruditapes decussatus. J. Shellfish Res. 2008, 27, 1093-1100. [CrossRef]

43. Tseng, C.K. Algal biotechnology industries and research activities in China. J. Appl. Phycol. 2001, 13, 375-380. [CrossRef]

44. Carmona, R.; Kraemer, P.; Yarish, C. Exploring Northeast American and Asian species of Porphyra for use in an integrated finfish-algal aquaculture system. Aquaculture 2006, 252, 54-65. [CrossRef]

45. Gao, X.; Endo, H.; Nagaki, M.; Agatsuma, Y. Interactive effects of nutrient availability and temperature on growth and survival of different size classes of Saccharina japonica (Laminariales, Phaeophyceae). Phycologia 2017, 56, 253-260. [CrossRef]

46. Chatzifotis, S.; Panagiotidou, M.; Papaioannou, N.; Pavlidis, M.; Nengas, I.; Mylonas, C.C. Effect of dietary lipid levels on growth, feed utilization, body composition and 13 serum metabolites of meagre (Argyrosomus regius) juveniles. Aquaculture 2010, 307, 65-70. [CrossRef]

47. Antonopoulou, E.; Chatzigiannidou, I.; Feidantsis, K.; Kounna, C.; Chatzifotis, S. Effect of water temperature on cellular stress responses in meagre (Argyrosomus regius). Fish Physiol. Biochem. 2020, 46, 1075-1091. [CrossRef]

48. Kir, M.; Topuz, M.; Sunar, M.C.; Topuz, H. Acute toxicity of ammonia in meagre (Argyrosomus regius Asso, 1801) at different temperatures. Aquac. Res. 2015, 47, 3593-3598. [CrossRef]

49. Kir, M.; Topuz, H.; Sunar, M.C.; Topuz, M. Effect of temperature on acute toxicity of nitrite to meagre, (Argyrosomus regius Asso, 1801). J. World Aquac. Soc. 2015, 46, 564-568. [CrossRef]

50. Jordaan, A.; Kling, L. Determining the Optimal Temperature Range for Atlantic Cod (Gadus morhua) during Early Life; The institute of Marine Research: Bergen, Norway, 2003; pp. 46-62.

51. Kristjánson, T. Comparison of growth in Atlantic cod (Gadus morhua) originating from the northern and southern coast of Iceland reared under common conditions. Fish. Res. 2013, 139, 105-109. [CrossRef]

52. Petersen, M.; Steffensen, J. Preferred temperature of juvenile Atlantic cod (Gadus morhua) with different haemoglobin genotypes at normoxia and moderate hypoxia. J. Exp. Biol. 2002, 206, 359-364. [CrossRef] [PubMed]

53. Björnsson, B.; Steinarsson, A.; Árnason, T. Growth model for Atlantic cod (Gadus morhua): Effects of temperature and body weight on growth rate. Aquaculure 2007, 271, 216-226. [CrossRef]

54. Thorarensen, H.; Imsland, A.K.D.; Gústavsson, A.; Gunnarsson, S.; Árnasond, J.; Steinarsson, A.; Björnsdóttir, R. Potential interactive effects of ammonia and $\mathrm{CO}_{2}$ on growth performance and feed utilization in juvenile Atlantic cod (Gadus morhua L.). Aquaculture 2018, 484, 272-276. [CrossRef]

55. Siikavuopio, I.; Sæther, S. Effects of chronic nitrite exposure on growth in juvenile Atlantic cod, Gadus morhua. Aquaculture 2006, 255, 351-356. [CrossRef]

56. Grande, M.; Andersen, S. Critical thermal maxima for young salmonids. J. Freshw. Ecol. 1991, 5, 275-279. [CrossRef] 
57. Finstad, A.G.; Naesje, T.F.; Forseth, T. Seasonal variation in the thermal performance of juvenile Atlantic salmon (Salmo salar). Freshw. Biol. 2004, 49, 1459-1467. [CrossRef]

58. Oppedal, F.; Juell, J.; Tarranger, G.; Hansen, T. Artificial light and season affects vertical distribution and swimming behaviour of post-smolt Atlantic salmon in sea cages. J. Fish Biol. 2001, 58, 1570-1584. [CrossRef]

59. Johansson, D.; Ruohonen, K.; Kiessling, A.; Oppedal, F.; Stiansen, J.; Kelly, M.; Juell, J. Effect of environmental factors on swimming depth preferences of Atlantic salmon (Salmo salar L.) and temporal and spatial variations in oxygen levels in sea cages at a fjord site. Aquaculture 2006, 254, 594-605. [CrossRef]

60. Johansson, D.; Ruohonen, K.; Juell, J.; Oppedal, F. Swimming depth and thermal history of individual Atlantic salmon (Salmo salar L.) in production cages under different ambient temperature conditions. Aquaculture 2009, 290, 296-303. [CrossRef]

61. Friedland, K.D.; Hansen, L.P.; Dunkley, D.A.; MacLean, J.C. Linkage between ocean climate, post-smolt growth and survival of Atlantic salmon (Salmo salar L.) in the North Sea area. ICES J. Mar. Sci. 2000, 57, 419-429. [CrossRef]

62. Jonsson, B.; Jonsson, N. Factors affecting marine production of Atlantic salmon (Salmo salar). J. Fish. Aquacul. Sci. 2004, 61, 2369-2383. [CrossRef]

63. Olsvik, P.; Vikeså, V.; Lie, K.; Hevrøy, E. Transcriptional responses to temperature and low oxygen stress in Atlantic salmon studied with next-generation sequencing technology. BMC Genom. 2013, 14, 817. [CrossRef]

64. Jørgensen, S. Cardiac responses to elevated seawater temperature in Atlantic salmon. BMC Physiol. 2014, 14, 2. [CrossRef]

65. Hevrøy, E.; Tipsmark, C.; Remø, S.; Hansen, T.; Fukuda, M.; Torgersen, T.; Vikeså, V.; Olsvik, P.; Waagbø, R.; Shimizu, M. Role of the GH-IGF-1 system in Atlantic salmon and 37 rainbow trout postsmolts at elevated water temperature. Comp. Biochem. Physiol. Part A Mol. Integr. Physiol. 2015, 188, 127-138. [CrossRef]

66. Elliott, J.M.; Elliott, J.A. Temperature requirements of atlantic salmon Salmo salar, brown trout Salmo trutta and arctic charr Salvelinus alpinus: Predicting the effects of climate change. J. Fish Biol. 2010, 77, 1793-1817. [CrossRef]

67. Knoph, M.B. Acute toxicity of ammonia to Atlantic salmon (Salmo salar) parr. Comp. Biochem. Physiol. Part C Comp. Pharmacol. 1992, 101, 275-282. [CrossRef]

68. Kolarevic, J.; Selset, R.; Felip, O.; Good, C.; Snekvik, K.; Takle, H.; Terjesen, B.F. Influence of long term ammonia exposure on Atlantic salmon (Salmo salar L.) parr growth and welfare. Aquac. Res. 2012, 44, 1649-1664. [CrossRef]

69. Gutiérrez, A.; Kolarevic, J.; Takle, H.; Baeverfjord, G.; Ytteborg, E.; Fyhn, B. Effects of chronic sub-lethal nitrite exposure at high water chloride concentration on Atlantic salmon (Salmo salar, Linnaeus 1758) parr. Aquac. Res. 2019, 50, 2687-2697. [CrossRef]

70. Muller-Feuga, A. Modilisation dela Croissance des Poisons en Levage; Rapports Scientifiques et Techniques de l'Ifremer; Institut Français de Recherche pour l'Exploitation de la Mer, Archimer: Plouzané, France, 1990; Volume 21, pp. 26-28.

71. Bovo, G.; Borghesan, F.; Comuzzi, M.; Ceschias, G.; Giorgetti, G. "Winter disease” in orati di allevamento: Observazioni preliminary. Boll. Soc. Ital. 1995, 17, 2-11.

72. Ibarz, A.; Padrós, F.; Gallardo, M.Á. Low-temperature challenges to gilthead sea bream culture: Review of cold-induced alterations and 'Winter Syndrome'. Rev. Fish Biol. Fish. 2010, 20, 539-556. [CrossRef]

73. Tort, L.; Rotllant, J.; Rovira, L. Immunological suppression in gilthead sea bream Sparus aurata of the North-West Mediterranean at low temperatures. Comp. Biochem. Physiol. Part A Mol. Integr. Physiol. 1998, 120, 175-179. [CrossRef]

74. Seginer, I. Growth models of gilthead sea bream (Sparus aurata L.) for aquaculture: A review. Aquac. Eng. 2016, 70, 15-32. [CrossRef]

75. Guinot, D.; Ureña, R.; Pastor, A.; Varó, I.; Ramo, J.; Torreblanca, A. Long-term effect of temperature on bioaccumulation of dietary metals and metallothionein induction in Sparus aurata. Chemosphere 2012, 87, 1215-1221. [CrossRef]

76. Ravagnan, G. Valliculture du Loup et de la Daurade. In L'Aquaculture du Bar et des Sparid; Barnabé, G., Billard, R., Eds.; INRA Publication: Paris, France, 1984; pp. 361-372.

77. Barnabé, G. Rearing bass and gilthead bream. Aquaculture 1991, 2, 647-686.

78. Shields, R.J. Larviculture of marine finfish in Europe. Aquaculture 2001, 200, 55-88. [CrossRef]

79. Person-Le Ruyet, J.; Chartois, H.; Quemener, L. Comparative acute ammonia toxicity in marine fish and plasma ammonia response. Aquaculture 1995, 136, 181-194. [CrossRef]

80. Kir, M.; Sunar, M.C. Acute Toxicity of Ammonia and Nitrite to Sea Bream, Sparus aurata (Linnaeus, 1758), in Relation to Salinity. J. World Aquac. Soc. 2017, 49, 516-522. [CrossRef]

81. Claridge, P.N.; Potter, I.C. Movements, abundance, age composition and growth of bass, Dicentrarchus labrax, in the Severn Estuary and Inner Bristol Channel. J. Mar. Biol. Assoc. 1983, 63, 871-879. [CrossRef]

82. Kousoulaki, K.; Sæther, B.S.; Albrektsen, S.; Noble, C. Review on European sea bass (Dicentrarchus labrax, Linnaeus, 1758) nutrition and feed management: A practical guide for optimizing feed formulation and farming protocols. Aquacul. Nutr. 2015, 21, 129-151. [CrossRef]

83. Person-Le Ruyet, J.; Mahé, K.; Le Bayon, N.; Le Delliou, H. Effects of temperature on growth and metabolism in a Mediterranean population of European sea bass, Dicentrarchus labrax. Aquaculture 2004, 237, 269-280. [CrossRef]

84. Dulger, N.; Kumlu, M.; Türkmen, S.; Ölçülü, A.; Eroldoğan, O.; Yilmaz, H.; Öçal, N. Thermal tolerance of European Sea Bass (Dicentrarchus labrax) juveniles acclimated to three temperature levels. J. Therm. Biol. 2012, 37, 79-82. [CrossRef]

85. Zhang, Z.; Zhou, C.; Fan, K.; Liu, Y.; Liu, P. Metabolomics analysis of the effects of temperature on the growth and development of juvenile European seabass (Dicentrarchus labrax). Sci. Total Environ. 2021, 769, 145-155. [CrossRef] [PubMed] 
86. Saroglia, M.G.; Scarano, G.; Tibaldi, E. Acute toxicity of nitrite to sea bass (Dicentrarchus labrax) and european eel (Anguilla anguilla). J. World Maric. Soc. 1981, 12, 121-126. [CrossRef]

87. Ettahiri, O.; Berraho, A.; Houssa, R.; Ramzi, A.; Somoue, L.; Zizah, S.; Machu, E. Characteristics of the spawning habitats of sardine, Sardina pilchardus, off the Moroccan Atlantic coast $\left(21^{\circ} \mathrm{N}-26^{\circ} \mathrm{N}\right)$. Pech. Aquac. 2012, 18, 157-186.

88. Baloi, M.; Carvalho, C.V.A.; Sterzelecki, F.C.; Passini, G.; Cerqueira, V.R. Effects of feeding frequency on growth, feed efficiency and body composition of juveniles brazilian sardine, Sardinella brasiliensis (steindacher 1879). Aquac. Res. 2017, 47, 554-560. [CrossRef]

89. Fernández-Montero, A.; Caballero, M.J.; Torrecillas, S.; Izquierdo, M.S.; Montero, D. Effect of temperature on growth performance and immunological parameters of greater amberjack Seriola dumerili juveniles. Fish Shellfish Immunol. 2016, 53, 105. [CrossRef]

90. Abbink, W.; Blanco Garcia, A.; Roques, J.A.C.; Partridge, G.J.; Kloet, K.; Schneider, O. The effect of temperature and pH on the growth and physiological response of juvenile yellowtail kingfish Seriola lalandi in recirculating aquaculture systems. Aquaculture 2012, 330, 130-135. [CrossRef]

91. Widdows, J. Combined effects of body size, food concentration and season on the physiology of Mytilus edulis. J. Mar. Biol. Assoc. 1978, 58, 109-124. [CrossRef]

92. Bayne, B.L.; Bayne, C.J.; Carefoot, T.C.; Thompson, R.J. The physiological ecology of Mytilus californianus Conrad. Metabolism and energy balance. Oceon 1976, 22, 211-228.

93. Almada-Villela, P.C.; Davenport, J.; Gruffydd, L.L.D. The effects of temperature on the shell growth of young Mytilus edulis L. J. Exp. Mar. Biol. Ecol. 1982, 59, 275-288. [CrossRef]

94. Kittner, C.; Risgaard, H. Effect of temperature on filtration rate in the mussel Mytilus edulis: No evidence for temperature compensation. Mar. Ecol. Prog. Ser. 2005, 305, 147-152. [CrossRef]

95. Riisgard, H.U.; Lassen, J.; Kittner, C. Valve-gape response times in mussels (Mytilus edulis) Effects of laboratory preceding-feeding conditions and in situ tidally induced variation in phytoplankton biomass. J. Shellfish Res. 2006, 25, 901-911.

96. Pascoe, P.L.; Parrym, H.E.; Hawkins, A.J.S. Observations on the measurement and interpretation of clearance rate variations in suspension-feeding bivalve shellfish. Aquat. Biol. 2009, 6, 181-190. [CrossRef]

97. Brynjelsen, E.; Strand, O. Test production of king scallop in intermediate culture 1995-1996. Aquac. Int. 1996, 18, 34.

98. Laing, I. Effect of temperature and ration on growth and condition of king scallop (Pecten maximus) spat. Aquaculture 2000, 183, 325-334. [CrossRef]

99. Davenport, J.; Gruffydd, D.; Beaumont, A.R. An apparatus to supply water of fluctuating salinity and its use in a study of the salinity tolerance of larvae of the scallop Pecten maximus L. J. Mar. Biol. 1975, 55, 391-409. [CrossRef]

100. Hawkins, L.E.; Hutchinson, S.; Laing, I. The effects of temperature and food ration on metabolite concentrations in newly settled king scallop (Pecten maximus) spat. Aquaculture 2005, 250, 841-848. [CrossRef]

101. Bergvik, M.; Stensås, L.; Handå, A.; Reitan, K.I.; Strand, Ø.; Olsen, Y. Incorporation of Feed and Fecal Waste from Salmon Aquaculture in Great Scallops (Pecten maximus) Co-fed by Different Algal Concentrations. Adv. Mar. Sci. 2019, 5. [CrossRef]

102. Fabioux, C.; Huvet, A.; Le Souchu, P.; Le Pennec, M.; Pouvreau, S. Temperature and photoperiod drive Magallana gigas reproductive internal clock. Aquaculture 2005, 250, 458-470. [CrossRef]

103. Moreira, A.; Figueira, E.; Libralato, G.; Soares, A.M.V.M.; Guida, M.; Freitas, R. Comparative sensitivity of Magallana angulata and Magallana gigas embryo-larval development to as under varying salinity and temperature. Mar. Environ. Res. 2018, 140, 134-144. [CrossRef] [PubMed]

104. Portela, T. Distribuição e Recrutamento da Ostra-Portuguesa, Crassostrea angulata (Lamarck, 1819), No Estuário do Sado. Master's Thesis, Universidade de Lisboa, Lisbon, Portugal, 2016.

105. Qiu, T.; Liu, Y.; Zheng, J.; Zhang, T.; Qi, J. A feeding model of oyster larvae (Magallana angulata). Physiol. Behav. 2015, 147, 169-174. [CrossRef] [PubMed]

106. Albentosa, M.; Camacho, A.P.; Beiras, R. The effect of food concentration on the scope for growth and growth performance of Ruditapes decussatus (L.) seed reared in an open-flow system. Aquac. Nutr. 1996, 2, 213-220. [CrossRef]

107. Matias, D.; Joaquim, S.; Leitão, A.; Massapina, C. Effect of geographic origin, temperature and timing of broodstock collection on conditioning, spawning success and larval viability of Ruditapes decussatus (Linné, 1758). Aqua. Int. 2009, 17, 257-271. [CrossRef]

108. Sobral, P.; Fernandes, S. Physiological responses and scope for growth of Ruditapes decussatus from Ria Formosa, southern Portugal, exposed to increased ambient ammonia. Sci. Mar. 2004, 68, 219-225. [CrossRef]

109. Aranda-Burgos, J.A.; da Costa, F.; Nóvoa, S.; Ojea, J.; Martínez-Patiño, D. Effects of microalgal diet on growth, survival, biochemical and fatty acid composition of Ruditapes decussatus larvae. Aquaculture 2014, 420, 38-48. [CrossRef]

110. Rebello, J.; Ohno, M.; Critchley, A.T.; Sawamura, M. Growth Rates and Agar Quality of Gracilaria gracilis (Stackhouse) Steentoft from Namibia, Southern Africa. Bot. Mar. 1996, 39, 273-280. [CrossRef]

111. Raikar, S.; Lima, M.; Fujita, Y. Effect of temperature, sannity and light intensity on the growth of Gracilaria spp. (Gracilariales, Rhodophyta) from Japan, Malaysia and India. Indian J. Sci. 2001, 30, 98-104.

112. Engledow, H.R.; Bolton, J.J. Environmental tolerances in culture and agar content of Gracilaria verrucosa (Hudson) Papenfuss (Rhodophyta, Gigartinales) from Saldanha Bay. S. Afr. J. Bot. 1992, 58, 263-267. [CrossRef]

113. Green, L.A.; Neefus, C.D. Effects of temperature, light level, and photoperiod on the physiology of Porphyra umbilicalis Kützing from the Northwest Atlantic, a candidate for aquaculture. J. Appl. Phycol. 2016, 28, 1815-1826. [CrossRef] 
114. Kraemer, G.; Yarish, C. A preliminary comparison of the mariculture potential of Porphyra purpurea and Porphyra umbilicalis. J. Appl. Phycol. 1999, 11, 473-477. [CrossRef]

115. Kim, J.K.; Kraemer, G.P.; Neefus, C.D.; Chung, I.K.; Yarish, C. Effects of temperature and ammonium on growth, pigment production and nitrogen uptake by four species of Porphyra (Bangiales, Rhodophyta) native to the New England coast. J. Appl. Phycol. 2007, 19, 431-440. [CrossRef]

116. Hafting, J.T. Effect of tissue nitrogen and phosphorus quota on growth of Porphyra yezoensis blades in suspension cultures. In Proceedings of the Sixteenth International Seaweed Symposium, Cebu City, Philippines, 12-17 April 1998; Springer: Dordrecht, The Netherlands, 1999; pp. 305-314.

117. Endo, H.; Okumura, Y.; Sato, Y.; Agatsuma, Y. Interactive effects of nutrient availability, temperature, and irradiance on photosynthetic pigments and color of the brown alga Undaria pinnatifida. J. Appl. Phycol. 2016, 29, 1683-1693. [CrossRef]

118. Saito, Y. Practical significance of algae in Japan: Undaria. In Advance of Phycology in Japan; Tokida, J., Hirose, H., Eds.; Springer: Berlin/Heidelberg, Germany, 1975; pp. 304-320.

119. Salas-Leiton, E.; Vieira, L.R.; Guilhermino, L. Sustainable Fishing and Aquaculture Activities in the Atlantic Coast of the Portuguese North Region: Multi-Stakeholder Views as a Tool for Maritime Spatial Planning. Sustainability 2021, 13, 663. [CrossRef]

120. Mota, V.; Nilsen, T.; Gerwins, J.; Gallo, M.; Ytteborg, E.; Baeverfjord, G.; Terjesen, B.F. The effects of carbon dioxide on growth performance, welfare, and health of Atlantic salmon post-smolt (Salmo salar) in recirculating aquaculture systems. Aquaculture 2018, 498, 578-586. [CrossRef]

121. Kounna, C.; Fountoulaki, E.; Miliou, H.; Chatzifotis, S. Water temperature effects on growth performance, proximate body and tissue composition, morphometric characteristics and gastrointestinal evacuation processes of juvenile meagre, Argyrosomus regius (Asso 1801). Aquaculture 2021, 540, 736683. [CrossRef]

122. Sales, R.; Galafat, A.; Vizcaíno, A.; Sáez, M.; Martínez, T.; Cerón-García, M.; Alarcón, J. Effects of dietary use of two lipid extracts from the microalga Nannochloropsis gaditana (Lubián, 1982) alone and in combination on growth and muscle composition in juvenile gilthead seabream, Sparus aurata. Algal Res. 2021, 53, 102162. [CrossRef]

123. Zhou, C.; Zhang, Z.; Zhang, L.; Liu, Y.; Liu, P. Effects of temperature on growth performance and metabolism of juvenile sea bass (Dicentrarchus labrax). Aquaculture 2021, 537, 736458. [CrossRef]

124. Bendiksen, E.Å.; Jobling, M.; Arnesen, A.M. Feed intake of Atlantic salmon parr Salmo salar L. In relation to temperature and feed composition. J. Aquac. Res. Dev. 2002, 33, 525-532. [CrossRef]

125. Handeland, S.O.; Imsland, A.K.; Stefansson, S.O. The effect of temperature and fish size on growth, feed intake, food conversion efficiency and stomach evacuation rate of Atlantic salmon post-smolts. Aquaculture 2008, 283, 36-42. [CrossRef]

126. Shapawi, R.; Abdullah, F.; Senoo, S.; Mustafa, S. Nutrition, growth and resilience of tiger grouper (Epinephelus fuscoguttatis) $\times$ giant grouper (E. lanceolatus) hybrid-A review. Rev. Aquac. 2018, 11, 1285-1296. [CrossRef]

127. Quéméner, L. Le Maigre Commun (Argyrosomus regius): Biologie, Pêche, Marché et Potentiel Aquacole; IFREMER: Plouzané, France, 2002.

128. Morales-Nin, B.; Geffen, A.J.; Pérez-Mayol, S.; Palmer, M.; González-Quirós, R.; Grau, A. Seasonal and ontogenic migrations of meagre (Argyrosomus regius) determined by otolith geochemical signatures. Fish. Res. 2012, 127-128, 154-165. [CrossRef]

129. Ibarz, A.; Fernández-Borràs, J.; Blasco, J.; Gallardo, M.A.; Sánchez, J. Oxygen consumption and feeding rates of gilthead sea bream (Sparus aurata) reveal lack of acclimation to cold. Fish Physiol. Biochem. 2003, 29, 313-321. [CrossRef]

130. Kır, M. Thermal tolerance and standard metabolic rate of juvenile gilthead seabream (Sparus aurata) acclimated to four temperatures. J. Therm. Biol. 2020, 93, 102739. [CrossRef]

131. Bandarra, N.; Marçalo, A.; Cordeiro, A.; Pousão-Ferreira, P. Sardine (Sardina pilchardus) lipid composition: Does it change after one year in captivity? Food Chem. 2018, 244, 408-413. [CrossRef]

132. Marçalo, A.; Pousão-Ferreira, P.; Mateus, L.; Duarte Correia, J.; Stratoudakis, Y. Sardine early survival, physical condition and stress after introduction to captivity. J. Fish Biol. 2008, 72, 103-120. [CrossRef]

133. Monge-Ortiz, R.; Martínez-Llorens, S.; Lemos-Neto, M.; Falcó-Giaccaglia, S.; Pagán, M.; Godoy-Olmos, S.; Tomás-Vidal, A. Growth, sensory and chemical characterization of Mediterranean yellowtail (Seriola dumerili) fed diets with partial replacement of fish meal by other protein sources. Aquac. Rep. 2020, 18, 100466. [CrossRef]

134. Jerez, S.; Samper, M.; Santamaría, F.J.; Villamandos, J.E.; Cejas, J.R.; Felipe, B.C. Natural spawning of greater amberjack (Seriola dumerili) kept in captivity in the Canary Islands. Aquaculure 2006, 252, 199-207. [CrossRef]

135. Weir, I.; Fawcett, S.; Smith, S.; Walker, D.; Bornman, T.; Fietz, S. Winter biogenic silica and diatom distributions in the Indian sector of the Southern Ocean. Deep Sea Res. Part A Oceanogr. Res. Pap. 2020, 166, 103421. [CrossRef]

136. Pernet, F.; Malet, N.; Pastoureaud, A.; Vaquer, A.; Quéré, C.; Dubroca, L. Marine diatoms sustain growth of bivalves in a Mediterranean lagoon. J. Sea Res. 2012, 68, 20-32. [CrossRef]

137. Miossec, L.; Le Deuff, R.M.; Goulletquer, P. Alien Species Alert: Magallana gigas (Pacific Oyster); ICES Cooperative Research Report No. 299; International Council for the Exploration of the Sea: Copenhagen, Denmark, 2009.

138. Malouf, R.E.; Breese, W.P. Seasonal changes in the effects of temperature and water flow rate on the growth of juvenile Pacific oysters, Magallana gigas (Thunberg). Aquaculture 1977, 12, 1-13. [CrossRef]

139. Peinado, I.; Girón, J.; Koutsidis, G.; Ames, J.M. Chemical composition, antioxidant activity and sensory evaluation of five different species of brown edible seaweeds. Food Res. Int. 2014, 66, 36-44. [CrossRef] 
140. Capillo, G.; Sanfilippo, M.; Aliko, V.; Spano, N.; Spinelli, A.; Manganaro, A. Gracilaria gracilis, Source of Agar: A Short Review. Curr. Org. Chem. 2017, 21, 380-386.

141. Fortes, M.D.; Lüning, K. Growth rates of North Sea macroalgae in relation to temperature, irradiance and photoperiod. Helgol. Meeresunters 1980, 34, 15-29. [CrossRef]

142. Blouin, N.; Xiugeng, F.; Peng, J.; Yarish, C.; Brawley, S.H. Seeding nets with neutral spores of the red alga Porphyra umbilicalis (L.) Kützing for use in integrated multitrophic aquaculture (IMTA). Aquaculture 2007, 270, 77-91. [CrossRef]

143. Fairhead, V.A.; Cheshire, A.C. Seasonal and depth related variation in the photosynthesis-irradiance response of Ecklonia radiata (Phaeophyta, Laminariales) at West Island, South Australia. Mar. Biol. 2004, 145, 415-426. [CrossRef]

144. Gao, X.; Endo, H.; Taniguchi, K.; Agatsuma, Y. Genetic differentiation of high-temperature tolerance in the kelp Undaria pinnatifida sporophytes from geographically separated populations along the Pacific coast of Japan. J. Appl. Phycol. 2012, 25, 567-574. [CrossRef]

145. Goseberg, N.; Chambers, M.D.; Heasman, K.; Fredricksson, D.; Fredheim, A.; Schlurmann, T. Technological approaches to longline and cage-based aquaculture in the open ocean. In Aquaculture Perspective of Multi-Use Sites in the Open Ocean; Buck, B.H., Langan, R., Eds.; Springer: Berlin/Heidelberg, Germany, 2017; pp. 71-96.

146. Moe, H.; Fredheim, A.; Hopperstad, O.S. Structural analysis of aquaculture net cages in current. J. Fluids Struct. 2010, $26,503-516$. [CrossRef]

147. Kristiansen, T.; Faltinsen, O.M. Experimental and numerical study of an aquaculture net cage with floater in waves and current. J. Fluids Struct. 2015, 54, 1-26. [CrossRef]

148. Tang, H.J.; Yeh, P.H.; Huang, C.C.; Yang, R.Y. Numerical study of the mooring system failure of aquaculture net cages under irregular waves and current. Ocean Eng. 2020, 216, 108110. [CrossRef]

149. Juell, J.; Fosseidengen, J. Use of artificial light to control swimming depth and fish density of Atlantic salmon (Salmo salar) in production cages. Aquaculture 2004, 233, 269-282. [CrossRef]

150. Dempster, T.; Korsøen, Ø.; Folkedal, O.; Juell, J.; Oppedal, F. Submergence of Atlantic salmon (Salmo salar L.) in commercial scale sea-cages: A potential short-term solution to poor surface conditions. Aquaculture 2009, 288, 254-263. [CrossRef]

151. Araújo, J.; Soares, F.; Medeiros, A.; Bandarra, N.M.; Freire, M.; Falcão, M.; Pousão-Ferreira, P. Depth effect on growth and fatty acid profile of Mediterranean mussel (Mytilus galloprovincialis) produced on a longline off south Portugal. Aquac. Int. 2020, 28, 927-946. [CrossRef] 